\title{
Origin and chronology of the Augias deposit in the lonian Sea (Central Mediterranean Sea), based on new regional sedimentological data
}

\author{
San Pedro L. ${ }^{1,{ }^{*},}$ Babonneau Nathalie ${ }^{1}$, Gutscher M.-A. ${ }^{1}$, Cattaneo Antonio ${ }^{2}$ \\ ${ }_{1}^{1}$ Laboratoire Domaines Océaniques, UMR 6538, Université de Brest - IUEM -, Plouzané, France \\ 2 IFREMER, Institut Carnot EDROME, Géosciences Marines, Plouzané, France \\ * Corresponding author : L. San Pedro, email address : laurine.sanpedro@univ-brest.fr
}

\begin{abstract}
:
In the Ionian Sea (Central Mediterranean Sea), several thick acoustically transparent layers are present including the Augias deposit. The Augias deposit is the most recent, thick layer covering the entire floor of the lonian Abyssal Plain with an average thickness of 10-12 $\mathrm{m}$ and a maximum thickness of up to 24 $\mathrm{m}$ in the Sirte Abyssal Plain. This deposit has also been observed in several adjacent smaller basins in waters deeper than $3000 \mathrm{~m}$. Its estimated volume is $>65 \mathrm{~km} 3$. There are multiple plausible hypotheses regarding its age and triggering event, which include the $1600 \mathrm{BC}$ Santorini volcanic caldera collapse, the 365 AD Crete M 8.5 earthquake and other smaller earthquakes such as the 374 AD Calabria M 6.3 earthquake and the 361 AD Sicily M 6.6 earthquake. Understanding the cause of this mass-transport deposit is crucial for improving the natural hazard assessment of a vast area between southern Italy and western Greece. In this study, we propose a new interpretation of the Augias deposit in terms of sedimentary processes and origin, based on sediment cores collected in the NW lonian Sea during the CIRCEE cruise onboard R/V Le Suroit in October 2013.

The sedimentological analysis of seven piston cores reveals three sedimentary facies corresponding to the Augias deposit: 1) "homogenite", 2) "megaturbidite" and 3) "thick sandy turbidite". These sedimentary facies are distributed within specific morpho-tectonic regions as defined by newly acquired bathymetric data, indicating a strong control by transport and depositional processes. Sixteen radiocarbon dates obtained above and below the Augias deposit indicate a possible time window of about 500 years. This means that we cannot definitively prove a link to the 365 AD Crete earthquake, but we regard it as the most likely trigger. Other depositional models may be plausible, but here we propose a sequence of events as follows: (1) earthquake shock and possible triggering of submarine mass flow in the eastern part of the lonian Sea (western Hellenic subduction zone); (2) tsunami waves amplified by the confined morphology of the Sicily and Calabria continental shelves inducing an intense re-suspension of fine-grained sediment and massive destabilization at the heads of submarine canyons triggering turbidity currents; (3) gravity driven downslope transport of suspended sediment towards the deep basin and decantation; and (4) a final stage of decantation from seiche waves forming the majority of the homogenite facies in the Ionian Abyssal Plain.
\end{abstract}

Keywords : submarine paleoseismology ; Ionian Sea ; Homogenite ; Megaturbidite ; Augias deposit 


\section{Introduction}

Several acoustically transparent layers are found in at least three different basins in the Mediterranean Sea: the Herodotus basin (in the eastern Mediterranean Sea) (Reeder et al., 2000); the Balearic Abyssal Plain (in the western Mediterranean Sea) (Rothwell et al., 1998); the lonian Sea (in the central Mediterranean Sea) (Cita and Aloisi, 2000; Hieke and Werner, 2000; Polonia et al, 2013; Fig. 1). Several hypotheses have been proposed regarding their origin and triggering mechanisms, all associated to catastrophic events (volcanic activity, megathrust earthquakes, tsunamis ...). Identifying the parameters that have influenced the deposition of such layers is crucial to strengthen our understanding of geohazard in the Mediterranean Sea region. The present paper focuses on the most recent acoustically transparent layer found in the Ionian Sea, named hereinafter the Augias deposit. This layer 
offers an excellent opportunity to disentangle at least part of the open questions concerning the origin of those acoustically transparent layers, because it is a relatively accessible deposit - buried only a few metres below the seafloor - and it is present in a sedimentary succession rich in stratigraphic markers (e.g. sapropels and tephras; Fig. 2). The Augias deposit was first described by Kasten and Cita (1981) in the Ionian Sea. Since then, several oceanographic campaigns across the central and eastern Mediterranean Sea have collected kilometres of echosounder profiles and more than 50 cores to unravel the distribution, properties, origin and triggering mechanisms of such sedimentary unit (Fig. 3). However, no definitive answers have been provided concerning its depositional process and origin. Additional data acquired during the recent CIRCEE survey onboard R/V Le Suroit in October 2013 provide new evidence to understand the suite of processes, which formed the Augias deposit (Fig. 1).

This paper presents a high-resolution analysis of a set of piston cores collected across a wide range of geomorphological settings of the Ionian Sea that highlight the spatial variability in terms of thickness and sedimentary facies within the Augias deposit. The objectives are to estimate the age and origin of the Augias deposit, and to describe the sedimentary processes and the triggering mechanism that produced this type of thick deposit in the Mediterranean Sea region.

\section{Geological setting}

\subsection{Seismotectonic setting of the Calabrian Arc}

The Ionian Sea is a deep and narrow basin in the Central Mediterranean Sea. It is bounded by two accretionary wedges formed by the Calabrian and the Hellenic subduction zones, respectively to the northwest and to the east (Fig. 1).

The Calabrian accretionary wedge (Fig. 1) is caused in part by the convergence between the African and Eurasian plates (D'Agostino et al., 2008) as well as by the roll-back of the Ionian-Tyrrhenian slab towards the southeast. The Calabrian accretionary wedge is bounded to the west by the Sicily margin, characterized by the Malta escarpment, and to the north- 
east by the Apulian escarpment. The Malta escarpment is an extremely steep continental slope bordering the Ionian Sea and marks a transition between the Hyblean continental platform (with shallow water carbonates), to the west and a deep marine environment to the east (3000-4000 $\mathrm{m}$ depth). The dip of the slope varies between $10^{\circ}$ and $30^{\circ}$ and the escarpment is deeply incised by submarine canyons (Gutscher et al., 2015).

Based on the interpretation of seismic profiles, Polonia et al. (2011) suggested three morpho-structural domains of the Calabria accretionary wedge. They are identified following different tectonic processes (frontal accretion, overlap and fault complex): the postMessinian wedge, the pre-Messinian wedge and the inner plateau (Polonia et al, 2011).

Rapid Holocene uplift is reported in the region, with $2.4 \mathrm{~mm} / \mathrm{yr}$ in eastern Sicily and between $1 \pm 0.1 \mathrm{~mm} / \mathrm{yr}$ and $2.1 \mathrm{~mm} / \mathrm{yr}$ in south-western Calabria (Westaway, 1993; Antonioli et al., 2006). This coastal uplift, favoured an increase of sediment discharge toward continental shelves, with possible sediment remobilization during earthquakes and tsunamis. A causal link between an earthquake and a turbidity current was provided by the 1908 Messina earthquake (M7.5). This earthquake generated a tsunami with maximum observed run-up of about $10 \mathrm{~m}$ striking the coast of Sicily and southern Calabria (Boschi et al., 2000). After these events, two successive submarine cable breaks occurred, in the strait of Messina and further south, in the Ionian Sea. These cable breaks were caused by the turbidity currents travelling downslope (Ryan and Heezen, 1965) (Fig. 1). The associated turbidite deposit was also recovered in sediment cores by Ryan and Heezen (1965) and more recently, by Polonia et al. (2013).

The Central Mediterranean Sea and specifically the Ionian Sea has been the site of destructive earthquakes sometimes associated with tsunami with waves of up to $10 \mathrm{~m}$ (Tinti et al., 2004). In the eastern Mediterranean Sea, the 365 AD Crete is a historical earthquake that created a major tsunami wave felt along the African, Sicilian and Italian coasts according to written sources and simulations (Shaw et al., 2008). The magnitude of the 365 AD earthquake is estimated to have been M8 or even higher (Ambraseys al al., 1994) and it generated $9 \mathrm{~m}$ of uplift in western Crete (Pirazzoli et al., 1982, 1996). The earthquake and 
subsequent tsunami destroyed many towns along the coast of Crete. The tsunami itself hit Central and Eastern Mediterranean Sea and flooded several towns in Libya, Cyprus, Greece, Egypt, the Adriatic and the Sicily coast and destroyed Alexandria in Egypt (Stiros, 2001).

\subsection{Late Quaternary sedimentation in the Ionian Sea}

Different facies have been described in sediment cores sampled in the Ionian Sea: sapropel layers, tephra layers, turbidite deposits and thick transparent layers (homogenites and megaturbidites) (Fig. 2). The definitions of these facies are summarized in Table 1. These different facies are intercalated with hemipelagic deposits, which in the Ionian Sea, are characterized by clay layers usually containing planktonic foraminifera, pteropods and shell debris.

\subsection{The Augias deposit in the literature}

The Augias deposit is regionally extensive, covering both the Ionian and Sirte Abyssal Plains and the volume calculated of the mobilized sediment is estimated to be at least 65 $\mathrm{km}^{3}$ (Hieke and Werner, 2000). The thickness of the Augias deposit mapped by Hieke and Werner, (2000; Fig. 3) varies within the Ionian Sea area. Thickness variations are observed between the Calabrian Rise (accretionary wedge) and the Western Mediterranean ridge where the sedimentary sequence is incorporated into the "undulation zone" (Hinz, 1974).In the Sirte Abyssal Plain, the thickness of the Augias deposit increases from the northwest to the southeast from about $10 \mathrm{~m}$ to $18 \mathrm{~m}$, with a maximum thickness of $24 \mathrm{~m}$ found in the small south-eastern portion of the Sirte Abyssal Plain. In the Ionian Abyssal Plain, the thickness of Augias deposit remains nearly constant over large parts of the plain and the maximum thickness is 10 to $12 \mathrm{~m}$.

In the literature, the Augias deposit is described as composed of different facies depending on its location in the lonian Sea: type A and type B. 
Type $A$ is a pelagic turbidite less than $10 \mathrm{~m}$ thick. The base is consistently conformable and without obvious erosion (Cita and Aloisi, 2000). The pelagic fraction contains planktonic foraminifera and pteropods and is homogeneous. This deposit is observed in small perched basins of the Calabrian and Mediterranean wedge. The origin of the Augias deposit of type A is linked to resuspension and decantation of sediment after the repeated passage of tsunami waves (Cita and Aloisi, 2000).

Type $B$ is described as a terrigenous turbidite of several metres in thickness (with a maximum thickness of $24 \mathrm{~m}$; Rothwell, 1995). The base consists of a well-sorted sandy unit composed of well-rounded mica flakes and biogenic components (including Bryozoa, gastropods, benthic and planktonic foraminifera) and contains occasional secondary laminae of coarser material (Cita and Aloisi, 2000). Above the normal-graded base, the deposit is a homogeneous structureless muddy layer. The carbonate content increases at the base of the homogeneous part, explained by the presence of aragonite, which is interpreted as skeleton fragments of the green algae Halimeda sp. (Hieke, 1984). This type B deposit is located in the Ionian and Sirte Abyssal Plains and extends to east basin to Cyrene Seamount (Western Herodotus). The inferred sediment source was the inner plateau of the Sirte Gulf where the tsunami wave was particularly destructive (Hieke, 1984). The first age estimation of the Augias deposit was indirectly determined in the Ionian Abyssal Plain with a linear interpolation of sedimentation rates between the top sapropel S1 and base of Augias deposit, assuming no erosion (Kasten and Cita, 1981): the estimated age resulted between 3100 and 4400 years BP. It was first proposed that the Augias deposit was linked to a megatsunami, because it covers the entire lonian Abyssal Plain. Its origin was initially associated to the Bronze Age catastrophic eruption of Santorini dated at 3500 yr BP (Kasten and Cita, 1981). More recent work with new sediment cores and radiocarbon dates presented the 365 AD Crete earthquake as the most likely candidate to be the triggering event for the Augias deposit (Polonia et al., 2013).

\section{Data and methods}




\subsection{Bathymetry and Chirp profiles}

Geophysical and sedimentological data were collected during the CIRCEE cruise in October 2013 on the R/V Le Suroit. The data includes piston cores (Kullenberg corer), Chirp echosounder profiles and bathymetric data.

The bathymetric map is based on a compilation of several surveys including EM300 multibeam data (RV Le Suroit), EM7150 multibeam data (RV Pourquoi Pas?), EM120 multibeam data (RV Meteor) and different bathymetric data such as MediMap (Loubrieu et al., 2007) and GEBCO. The processing of the data provided a final grid of $60 \times 60 \mathrm{~m}$ and a vertical resolution around $2 \mathrm{~m}$.

Chirp echosounder profiles were acquired along the multibeam bathymetry surveys of CIRCEE with a signal frequency that varies between $5300 \mathrm{~Hz}$ to $1800 \mathrm{~Hz}$, a penetration in the sediment of about $80 \mathrm{~m}$ and a resolution about $0.75 \mathrm{~m}$.

\subsection{Core data and analyses}

Seven cores were collected in the lonian Sea during the CIRCEE cruise, at water depth between 3300 and $4050 \mathrm{~m}$. The main characteristics of the cores are summarized in Table 2 (locations in Fig. 1). Visual description characterized the main lithologies and allowed to define sedimentary facies.

Physical parameters (Gamma-Density, Magnetic susceptibility and P-wave velocity) were acquired with a Multi-Sensor Core-Logger (Geotek Ltd) with a sampling interval of $1 \mathrm{~cm}$. The chemical composition of major elements is obtained with an Avaatech XRF Core-Scanner equipped with a variable optical system allowing measurements at resolutions between 10 and $0.1 \mathrm{~mm}$. The selected measurement area was $8 \mathrm{~mm}$ and the step-size was set at $1 \mathrm{~cm}$. Each core was analysed at 10, 30 and $50 \mathrm{kV}$ for specific sections. Sediment cores were sampled for grain-size analyses using a Malvern laser micro-granulometre, for the 0.01 $2000 \mu \mathrm{m}$ fraction; sample intervals are adapted and chosen according to sedimentary facies. The mineralogical composition of sandy layers was determined with stereomicroscope. 
The sediment core chronology is reconstructed with AMS radiocarbon dating on planktonic foraminifera (Table 3). Samples were collected at the top of cores and below the base of some turbidites in well-identified hemipelagite beds. We picked approximately $10 \mathrm{mg}$ of planktonic foraminifera specimens (mixed or two specific specimen) from the $>250 \mathrm{~mm}$ fraction. These samples were then analysed at the LMC14 "Laboratoire de Mesure du Carbone 14" at Saclay, France (ARTEMIS program). Radiocarbon ages were calibrated with CALIB REV7.0.4 software, using the MARINE13 calibration Curve (Reimer et al., 2009) and corrected for an average marine reservoir effect of $147 \pm 24$ years (i.e., South Adriatic, Italy and Zante, Greece, from CALIB database).

\section{$\underline{\text { 4. Results }}$}

\subsection{Morphological description of the study area}

The study area includes the western lobe of the Calabrian accretionary wedge, the Messina Strait, the submarine slope of the Malta Escarpment and the Ionian Abyssal Plain (Fig. 4). Distinct morphologic structures (Fig. 4) emerge from the analysis of bathymetric data, with different seafloor features that are expressions of various sedimentary and tectonic processes.

The abyssal plain is the deep basin located between the Mediterranean Ridge and Calabrian accretionary wedges, in the southern Ionian Sea. It is roughly defined by the 4000 m contour depth (IOC, 1981). The Ionian Abyssal Plain constitutes one of the forelands of the Mediterranean Ridge (Hieke et al., 2003). The nature of this deep abyssal plain is interpreted either as a Tethysian oceanic relic (Finetti, 1982; Catalano et al., 2001) or as a foundered and thinned continental crust (Hinz, 1974; Hieke et al, 2003; Roure et al., 2012). The abyssal plain is the sink of sedimentary transport systems and hosts the thickest Augias deposit (maximum 10-12 m).

The deformation front corresponds to a zone composed of small anticlinal ridges and it is marked by a gently undulating seafloor (Gallais et al., 2012). This domain is located between the lonian Abyssal Plain and small perched basins. The anticlinal ridges were formed during 
the subduction of the African plate under the Calabrian arc, along the front of deformation (Finetti, 1982; Minelli and Faccenna, 2010; Polonia et al., 2011; Gutscher et al., 2015). The limit between this domain and several perched basins is somewhat arbitrary because the ridge morphology changes progressively into a series of small perched basins when moving northwards within the Calabrian prism.

Perched basins are located on the deformation front of the accretionary wedge, more precisely on the post-Messinian accretionary wedge. They consist of small isolated basins surrounded by ridges formed by the accretionary wedge and named "cobblestone topography" (Cita et al., 1984; Cita et al., 1996), "small perched basins" (Cita and Aloisi, 2000), or "confined perched basins" (Polonia et al, 2013). These basins are elongated in the direction parallel to the deformation front. On average, these basins are 50-200 $\mathrm{m}$ deep, roughly $1-2 \mathrm{~km}$ wide and $5-15 \mathrm{~km}$ long. They have the same orientation as the anticlinal ridges and also change direction further north.

An area composed of large basins is located on the middle prism, at the limit between the post- and the pre-Messinian prism. This limit is marked by a small scarp (thrust fault) and roughly follows the $3000 \mathrm{~m}$ depth contour (Polonia et al., 2011). The basins vary in size from 10 to $30 \mathrm{~km}$ and are commonly connected by channels.

The western corridors represent the north-western and western extremity of the Calabrian prism, along the Sicilian continental margin and the Malta escarpment. The western corridors are formed by canyons and channels shaped by turbidity currents. Canyons and channels observed to the north of Ionian Sea, have their sources in Messina Strait and northeast Sicilian margin and terminate in large basins. Other canyons begin at east Sicilian Margin, Malta Escarpment and Medina seamounts, follow the deformation front and terminate in the lonian Abyssal Plain (Fig. 4).

Fields of sediment waves are observed at the foot of the Malta Escarpment and in the southern Ionian Abyssal Plain. These are oriented roughly orthogonal to the Malta Escarpment consistent with downslope turbidite transport in this valley and represent $20-50$ $\mathrm{m}$ high, and $5-10 \mathrm{~km}$ long ridges. The definition of these sedimentary structures is "large 
scale depositional bedforms, generated beneath a current flowing at, or close to, the seafloor" (Wynn et al., 2000).

\subsection{Core description}

Sediment cores that penetrate the entire vertical extent of the Augias deposit were acquired at seven locations as part of the CIRCEE data set (Fig 4a, 5 and 6, Table 2). The facies, observed in these cores, are described in Table 1.

Core $\mathrm{KCIR-03}$ is located in the western part of the post-Messinian accretionary wedge. The core is composed of three thick turbidites with fine sandy base and a few fine silty turbidites. Under each deposit, the color of the clay layer is orange/brown. The base of the core is characterized by a $1-\mathrm{m}$ thick, grayish clay layer.

Core $K C I R-05$ is located in the western part of the pre-Messinian accretionary wedge. This core consists of a succession of silty-clay turbidites alternating with gray clay layers. Between 210 and $360 \mathrm{~cm}$, we observed the sapropel S1 composed of shell debris and foraminifera sub- divided in 8 dark layers alternating with clay layer. The upper part is composed of a thick clay deposit (94 cm thick, megaturbidite; see Table 1) and a succession of fine silty turbidites alternating with clay layers.

Core KCIR-08 is located between two small anticlinal ridges, on the edge of the accretionary wedge. The lower part of this core is composed of a succession of four silty turbidites (5 to $20 \mathrm{~cm}$-thick) alternating with grayish clay layers. The upper part of the core is characterized by three gray silty turbidites showing normal grading and laminations. Between these two parts, a gray clay deposit is observed with a thickness of $386 \mathrm{~cm}$ (megaturbidite; see Table 1).

Core KCIR-09 is located between the Ionian Abyssal Plain and the edge of the deformation front of the accretionary wedge, in a small confined basin. The base of this core is characterized by silty-clay and silty turbidites alternating with grayish clay layers. A thick turbidite is observed (50 $\mathrm{cm}$ thick), followed by a thick gray muddy deposit with a silty base and laminations. The sapropel S1 is observed between 385 and $460 \mathrm{~cm}$, divided in 4 layers. 
The top of the core is composed of brown clay. Between the sapropel layer and the top, we observe a gray clay turbidite (315 $\mathrm{cm}$ thick, megaturbidite, see Table 1$)$.

Core $K C I R-12$ is located on a topographic high, in small anticlinal ridges, between the Ionian Abyssal Plain and the edge of the deformation front. The description of this core is similar to KCIR-09 with alternating silty-clay or silty turbidites and clay layers, with a thick turbidite $(60 \mathrm{~cm}$ thick). We observe sapropel $\mathrm{S} 1$ between 430 and $470 \mathrm{~cm}$, divided in 5 layers and a gray clay turbidite (374 cm thick, megaturbidite; see Table 1).Cores KCIR-10 and KCIR-11 were collected in small, perched basins on the accretionary wedge. The lower part of KCIR-10 core is composed of silty or fine sandy turbidites alternating with gray clay layers. One of the turbidites contains volcanic particles (pumices). The sapropel S1 is observed with some shell debris and divided in 5 layers. This core is mostly composed of a thick gray clay layer $(615 \mathrm{~cm}$ thick, homogenite; see Table 1). At the top of the cores, a pelagic clay layer and a thin silty-clay turbidite are present.

The base of the core KCIR-11 is composed of a thick gray clay layer (162 cm thick) with a laminated silty-clay base. Above this deposit, the composition is similar to core KCIR-10 with alternating silty-sandy turbidites and gray clay layers. One of the turbidites contains volcanic particles (pumices) and we also observed the sapropel S1 (non subdivided) and a thick gray clay layer (244.5 cm thick, homogenite; see Table 1$)$.

\subsection{Spatial variability of the Augias deposit.}

- Seismic description of the Augias deposit

The Augias deposit sampled in sediment cores is observed in Chirp profiles as a transparent layer of variable thickness (from tens of $m$ to a few tens of cm; Fig. 6, green layer). This transparent layer is visible in the abyssal plain, between anticlinal ridges and in perched basins. Although in some Chirp profiles this layer is not visible because the resolution is not sufficient its observed physical continuity in Chirp profiles allows us to correlate the Augias deposit between different cores as the same deposit. 
- Sedimentological facies of the Augias deposit

We observed similarities in the Augias deposit between among the seven cores studied. This deposit can be divided into three units common to all seven cores: (1) the basal interval; (2) the homogeneous muddy interval; and (3) the upper interval.

(1): the clay layer below the Augias deposit is beige oxidized clay. The transition to the Augias deposit is marked by an abrupt grain-size change from a clay layer to a silt / fine sand layer. The Augias basal interval is characterized by a silty / sandy well-sorted sediment, showing normal grading and laminations. In most of the cores, the basal contact is erosional and the coarser interval contains foraminifera and/or shell debris.

(2): the thickest unit of the Augias deposit is a grayish clay layer. This layer is homogeneous, well-sorted without visible laminations. The thickness varies depending on the core location in a range of 0.94 to $6.15 \mathrm{~m}$. The geochemical signature of this unit shows higher values in $\mathrm{Ca} / \mathrm{Ti}$ (with the exception of core KCIR-05).

(3): The top of the Augias deposit is marked by a sharp color change from gray to orange due to the oxidation of sediment above the Augias deposit. The top is marked by a thin oxidized black/brown level and a peak of $\mathrm{Ca} / \mathrm{Ti}$ interpreted as a higher amount of carbonate.

Due to these similarities, the Augias deposit could be correlated in all the seven CIRCEE cores studied here. However, within the Augias deposit itself we observed a high degree of variability from one core to another. The Augias deposit has been divided into three facies, according to thickness, grain size and composition (Table 4).

Facies 1 is visible in core KCIR-05 (Fig. 7). The basal interval is sandy, $40 \mathrm{~cm}$ thick and the basal contact is erosive. Grain size analysis indicates normal grading with $90 \%$ sand at the base decreasing to $5 \%$ at the top of this interval. The sand contains planktonic foraminifera, fragment of minerals (micas) and fragment of pyritised vegetal debris (Fig. 7). The geochemical signature of the base is marked by a low content of $\mathrm{Ca}$ and the presence of pyritised vegetal debris indicated by a peak of Bromium. As commonly observed in turbidites (Table 1), Facies 1 exhibits normal grading and the clay layer is thin. The upper part is laminated. Facies 1 is observed only in the north-western part of the Calabrian 
accretionary wedge, close to the East Sicilian margin. We name Facies 1 "thick sandy turbidite".

Facies 2 is observed in cores KCIR-08, KCIR-09 and KCIR-12 (Fig. 8). The base is erosive, coarse and laminated. The thickness of the base is roughly constant (about $1 \mathrm{~m}$ ). However, each core presents a peculiar sediment composition of the basal interval:

- KCIR-08: The basal interval is divided into two parts. The upper part $(370-400 \mathrm{~cm})$ has an abrupt change of $\mathrm{Ca}$ concentration and a low magnetic susceptibility. This basal interval is composed of up to $95 \%$ of planktonic foraminifera and some mineral fragments (micas) and volcanic pumice. The lower part of the basal interval (400-452 $\mathrm{cm}$ ) is laminated and marked by a low concentration of $\mathrm{Ca}$ and a peak of magnetic susceptibility. It is composed of foraminifera (mainly planktonic), bivalves and pteropod fragments.

- KCIR-09: The basal interval consists exclusively of planktonic foraminifera and some pteropod fragments.

- KCIR-12: the grain size of the basal interval is finer than in the other two cores with a peak at 50 microns. At the base, we observed only a few foraminifera and minerals.

We name Facies 2 "megaturbidite". It is located at the southern boundary of the Calabrian accretionary prism, in small basins (Fig. 4).

Facies 3 is described in cores KCIR-10 and KCIR-11 (Fig. 9). The basal interval is fine and thin or locally undifferentiated from underlying sediment. The sand content in the base is less than $50 \%$. No sedimentary structures are observed. The coarse content of the basal interval is only composed of foraminifera and some sponge spicules in KCIR-10. Facies 3 is observed within the accretionary wedge in small, perched basins and we name it "homogenite".

\subsection{Age model and sedimentation rate}

The chronostratigraphic framework of CIRCEE cores was established by radiocarbon dating (Fig. 10). In the Central Mediterranean Sea, two sedimentary facies can also be used 
as chronostratigraphic markers: tephras and sapropels (Fig. 10; in purple and black in log). However, the uncertainties of this method are too high for the last few thousand years. When sapropels are present in cores, they are mostly interfingered with fine turbidites. The identification of the top and base is too uncertain to use these deposits as stratigraphic markers.

The identification of tephras is based on chemical composition, the depth in the core (approximate stratigraphic location) and on visual identification of tephra (Keller et al., 1978; Insinga et al., 2014). Tephras observed in CIRCEE cores are composed of pumices which come from Mont Etna. The identification by chemistry of these pumices allows us to identify them as two tephra layers already described in the literature: the pre-Y1 and the $\mathrm{Y} 1$ tephra, dated respectively at $18.14 \mathrm{ka}$ BP and $16.7 \mathrm{ka}$ BP (Insinga et al., 2014). However, in CIRCEE cores most tephras are associated with turbidites. These are probably reworked and cannot be used directly as stratigraphic markers.

Hemipelagic sedimentation rates were calculated for each core with ${ }^{14} \mathrm{C}$ dates. These dates have other uncertainties including those due to the coring deformation, modifying the depth of each deposit in core, the apparent sedimentation rate and; uncertainties on the ${ }^{14} \mathrm{C}$ measurement: laboratory analytical precision; calibration procedure; reservoir age error (Lowe at al., 2007). For reservoir age, a mean deltaR was calculated in the basins around the Ionian Sea (CALIB software). This value is $147 \pm 24 \mathrm{yr}$ (i.e., South Adriatic, Italy and Zante, Greece, from CALIB database). Additional uncertainties concern the continuity of the sedimentary record with difficulties to estimate erosion at the base of turbidites. Other potential errors come from bioturbation and non-linearity in sediment accumulation which can created potential variations in the rate of hemipelagic accumulation (Pope et al., 2015). Hemipelagic sedimentation rates are calculated for each core between two ages collected below the Augias deposit, removing the turbidite deposits from the sedimentary column, by linear interpolation, as presented in Table 4. Sedimentation rates are different according to core location, varying from 8.1 to $28.4 \mathrm{~cm} / \mathrm{ka}$. The age of the base of Augias deposit is calculated in each core (assuming no erosion). It varies between $127.8 \pm 122 \mathrm{yr} \mathrm{BC}$ and 
$1407 \pm 131$ yr BC (Table 4). Furthermore, radiocarbon dates sampled above and below the Augias deposit allow to define a time window for this deposit. After age calibration, the Augias deposit results dated between $464 \pm 104 \mathrm{AD}$ and $127 \pm 122 \mathrm{BC}$.

\section{Discussion}

\subsection{Age of the Augias deposit and related event}

The acoustic facies and the continuity of the Augias deposit in Chirp profiles shows it is a synchronous event (Cita and Aloisi, 2000; Hieke, 1984; Hieke and Werner, 2000) (Fig. 6). Different events could have triggered turbidity currents: volcanic activity, collapse of the volcano, gas hydrate dissociation, earthquakes and/or tsunamis during the time window of the Augias deposit. However, there is no observed evidence of volcanic eruptions (tephras) nor collapse of the volcano (no volcanic particle in sediment succession and no historical archives). In the Ionian Sea, the gas hydrate existence is unknown. The most probable triggering event for the Augias event is an earthquake and/or a tsunami. For the range of plausible ages for the Augias deposit (464 \pm 104 AD to $127 \pm 122$ BC) (Fig. 11), only three earthquake events $(M>6)$ are known in this part of the Mediterranean Sea, based in the historical archive (e.g., Friedrich et al, 2006; Manning et al., 2006; Papadopoulos et al., 2010; Stiros, 2001; Polonia et al, 2013). They include: 1) the 361 AD Sicily earthquake $(M=6.6)$ with no available information regarding a possible tsunami; 2) the $365 A D$ Crete earthquake $(M>8)$ and the associated tsunami with an intensity of 6 based on the SiebergAmbraseys scale (Ambraseys, 1962); 3) the 374 AD Reggio Calabria earthquake $(M=6.3)$, with no available information regarding a possible tsunami.

The first hypothesis for the origin of the Augias deposit was the Santorini caldera collapse commonly dated at $3500 \mathrm{yr}$ BP (Kasten and Cita, 1981). In fact, more recent work on this event indicates a calendar date of 1627-1600 BC (Friederich et al., 2006, Manning et al., 2006). In either case, this event does not correspond to the ages calculated in our study (Fig. 11). The Augias deposit in the CIRCEE cores is dated well after the Santorini collapse event. It must therefore be linked to a more recent event. 
In the CIRCEE cores, the Augias deposit presents normal grading from the basal interval to the homogenous muddy interval and no erosion surface within the Augias deposit. This supports the interpretation that the deposit was laid down in a single event. Furthermore, in the Chirp data we observe the continuity of Augias deposit in the Ionian Abyssal Plain, in the Sirte Abyssal Plain and over the southern Calabrian wedge (CIRCEE data and Hieke, 2000). In order to create a deposit of such a relevant thickness over such a large area, the triggering event was likely very powerful in order to mobilize so much sediment. The most probable event corresponding to the age interval estimated for the Augias deposit is the 365 AD Crete earthquake and tsunami. The correlation between the Augias deposit and the 365 AD Crete earthquake was initially suggested by Vigliotti (2008), and recently strengthened by Polonia et al. (2013).

Onshore studies have reported tsunami deposits observed at several locations along the east coast of Sicily and in particular in Augusta Bay (De Martini et al., 2010; De Martini et al., 2012; Smedile et al., 2011; Smedile et al. 2012). These tsunami deposits are linked to major historical earthquakes and tsunami (for example, in Augusta Bay, the 1908, 1693 and 1169 events) and two far-field tsunamis (Crete 365 AD and Santorini 1600 BC). Geological evidence confirms that the Crete 365 AD tsunami strongly affected the entire eastern coast of Sicily (De Martini et al., 2012).

The main uncertainties of the age models are generated by the difficulty to estimate the amount of erosion at the base of the Augias deposit: this factor induces the high variability of age range. Assuming the Augias deposit was caused by the Crete earthquake (dated 365 AD), we have calculated potential erosion thickness at the base of this deposit.

Erosion of core KCIR-05 is about $27 \pm 3 \mathrm{~cm}$. This core is located near at the Sicilian Margin and Messina Strait, along the path of turbidity current. The continental sediment supply is more important and the turbidity current is more powerful (coarser grain size), inducing thicker erosion on the pathway. Core KCIR-08 presents an estimated erosion at the base of Augias of $11 \pm 4 \mathrm{~cm}$. The core location is near the pathway of turbidity currents, but it is isolated by anticlinal ridges. This location could explain the smaller amount of erosion at this 
core site. The amount of erosion below the Augias deposit estimated in the core KCIR-09 is the lowest of all CIRCEE cores $(5.2 \pm 1 \mathrm{~cm})$. KCIR-09, located in a small confined basin, is isolated by physiographic barriers and is not fed by terrestrial sediment sources. In core $\mathrm{KCIR}-12$, the erosion below the Augias deposit is calculated to be about $30.7 \pm 2 \mathrm{~cm}$. This core is collected in topographic high promoting erosion during the flow of turbidity current. Cores KCIR-10 and KCIR-11 are located in perched basins. The amount of erosion at the base of the Augias deposit is between $14.8 \pm 1 \mathrm{~cm}$ and $17 \pm 1 \mathrm{~cm}$. Our hypothesis to explain this erosion is: the pelagic sediment deposited in the perched basin is very fine (clay), and not consolidated, easily available for mobilization in low-density turbidity currents.

\section{$\underline{5.2 \text { Sedimentary processes }}$}

The Augias deposit is divided into three units and three sedimentary facies (Table 5) with different grain size, chemical and mineralogical composition (Fig. 7, 8, 9), providing information on sedimentary processes and sediment source (Fig. 12).

In core KCIR-05 (Facies 1, thick sandy turbidite; Fig. 7), the basal interval of Augias deposit contains fragments of pyritised vegetal debris and micas, indicating a continental source rich in organic matter. It also contains pumices suggesting a Sicily coast and Messina Strait source, near Etna. The erosive base indicates high-energy basal flow within the turbidity current. Turbidity currents generated during the Augias event were directed into several channels observed on the seafloor inducing high-energy flows and the deposit of the thick sandy turbidite facies. At this core site, the main sediment source therefore comes from the Messina straits area.

For cores KCIR-08, KCIR-09, and KCIR-12 (Facies 2 "megaturbidite"; Fig. 8), the grain size and the composition of the basal interval of Augias deposit are different, likely due to the geomorphological setting of core locations. The basal interval of core KCIR-08 is coarser and contains volcanic pumice, indicating a continental source as the Sicilian margin. Core KCIR-08 is located about $50 \mathrm{~km}$ from the foot of the Malta Escarpment. The grain size (silt) of basal interval of core KCIR-09 and KCIR-12 suggests a more distal character. The 
composition of the basal interval indicates a source along the Sicilian margin, possibly near the Etna volcano. The process linked to the deposition of the basal deposit is possibly a turbidity current triggered by the earthquake waves or tsunami generated after a $365 \mathrm{AD}$ Crete earthquake. The turbidity current followed the anticlinal ridges domain, between the Calabrian ridge and the Malta escarpment.

In cores KCIR-10 and KCIR-11 (Facies 3 "homogenite"; Fig. 9), the basal interval is fine and thin. Turbidity currents containing coarse-grained sediments apparently do not reach the small perched basins. The homogeneous part of Augias deposit is formed by sediment remobilisation and decantation of a nepheloid cloud after the triggering of multiple turbidity currents at different water depth, and after the resuspension of fine sediments generated by tsunami wave on the shelves. Local turbidity currents could have reworked the unconsolidated sediment present at the seabed and in perched basins (Mulder et al, 2009).

The homogeneous upper part of the Augias deposit covers the Ionian and Sirte Abyssal Plains and a large part of the Calabrian accretionary wedge (Fig. 12). The sediment volume was estimated at $65 \mathrm{~km}^{3}$ (Hieke and Werner, 2000) but, recent studies suggest it had a larger volume (Fig. 2).

\subsection{Augias event reconstruction}

The analysis of sedimentary facies and processes previously described allows us to propose a reconstruction of the Augias event in four stages (Fig. 13). This reconstruction is based on the assumption that the Augias deposit is linked to AD 365 Crete earthquake and tsunami.

The first stage is the triggering factor of the event. It is most likely associated to a major earthquake and, during the identified time window of 500 years, the AD 365 Crete earthquake is the most important, with a magnitude estimated around 8 (Fig. 13). Another study in the Ionian Sea has shown that earthquakes can trigger submarines gravity instabilities (Ryan and Heezen, 1965). So, with this order of magnitude, the seismic shock of the Crete earthquake probably triggered submarine gravity instabilities in the Hellenic 
subduction area. In the lonian basin, possible gravity flows could be triggered by the seismic shock but there are no available data to support this hypothesis.

The second stage is the impact of a large tsunami in the confined Ionian Sea (Fig. 13). Wave height was probably amplified by the morphology of the basin and the shelves and coastal areas could be reworked by the dynamics of large waves. Large volumes of sediments were likely eroded and fine-grained material was resuspended in the water column. Intense transport processes induced by the tsunami on shelves probably triggered numerous slope instabilities at the shelf break and especially in the canyon heads. Large turbidity currents may have occurred, as attested to by sandy turbidite and megaturbidite facies coming from the Messina strait. However, it is unclear if the seismic shock, the tsunami waves or the combined effects of both processes could have triggered turbidity currents.

The third stage corresponds to the reconcentration of fine-suspended sediment in the deepest part of the Ionian basin (Fig. 13). The process leading to the deposition of the homogenite (several metres thick of homogeneous structureless clay) is probably complex, combining gravity processes on the slope and decantation of the plume, with a possible role of the confined Ionian Basin in generating oscillatory flows (seiche effect, Mulder et al., 2009). Even if the homogenite facies can be interpreted as the exclusive result of decantation of clay rich sediment, the possible role of sediment gravity processes is attested by: (1) the absence of homogenite in water depth shallower than $3000 \mathrm{~m}$; (2) the variable thickness of the homogenite deposit with a strong thickening in basins and particularly in the Ionian Abyssal Plain (basin filling); and (3) the thick hemipelagic sediment gap estimated at the base of the homogenite in the small confined basins implying erosional processes.

The fourth stage is mainly decantation of the sediment plume concentrated in the deep part of the Ionian Basin, until the final deposition of the Augias deposit (Fig. 13).

Several large submarine landslides are described in the Mediterranean Sea (Camerlenghi et al., 2010) and globally (Bourget et al., 2013; Mulder et al., 2009; Wynn et al., 2010). The triggering mechanism of these events is often hard to prove unequivocally, as multiple 
potential triggers are possible (e.g., Urlaub et al., 2013). For example, the Herodotus Basin Megaturbidite (eastern Mediterranean) is linked to period of lowering sea level during the last glacial period. This change of sea level likely destabilised the outer shelf and created a megaturbidite with a thickness of 20 meters (Reeder et al., 2000). Another megaturbidite has also been identified in the Balearic Abyssal Plain in western Mediterranean (Rothwell et al., 1998). The estimated age is about the Last Glacial Maximum. The origin of this megaturbidite is still debated. The triggering event could be an earthquake/tsunami or gas hydrate dissociation, caused by a lowering of hydrostatic pressure on clathrate (linked to low sea level) (Rothwell et al., 1998).

\section{Conclusions}

The Augias deposit is an atypical sediment accumulation formed by a catastrophic event probably associated with a major tsunami in the Ionian Sea. On the basis of an integrated study of the regional distribution of the deposit, the sedimentological facies, the chemical composition, the potential age combined with the detailed morphology of the western lonian Sea, we propose a new model for the deposition processes of the Augias deposit.

New bathymetric data (including CIRCEE data) provide a more accurate morphological analysis of the seafloor, distinguishing six morphological domains: the Ionian Abyssal Plain, anticlinal ridges, perched basins, large basins, canyons and channels, and an area of sediment waves.

Seven sediment cores of the CIRCEE data set sampled the Augias deposit. The detailed sedimentological analysis of the Augias deposit allows us to distinguish three different sedimentary facies: facies 1 "thick sandy turbidite", facies 2 "megaturbidite" and facies 3 "homogenite". The regional distribution of the facies follows morphological areas and water depths and indicates different sedimentary processes associated to the Augias event.

Sedimentary facies, chemical composition within the same deposit (particularly in the basal interval) show the multi-source and multi-processes character of the Augias deposit. We 
propose that the sources are distributed all around the lonian basin. In this paper, we highlight: (1) a source of sediment coming from the Messina strait and Sicily coast by highenergy flows and turbidity currents; (2) turbidity currents from the Sicilian Margin to the Ionian Abyssal Plain, following the deformation front of the southern accretionary wedge; (3) the thickest part of the homogenite formed by fine-grained sediment remobilisation by tsunami wave and concentration of a nepheloid cloud in the deepest part of the lonian Sea. Our age models obtained by radiocarbon dating of the hemipelagic sediments, in agreement with the interpretation of Polonia et al. (2013), show that the 365 AD Crete earthquake and tsunami are the most likely events to explain the origin of the Augias deposit. We thus propose that the tsunami generated by the $365 \mathrm{AD}$ earthquake hit the eastern coast of Sicily and the Messina Strait triggering widespread submarine gravity instabilities and remobilizing fine-grained sediment.

\section{Acknowledgements}

We thank the Captain (Jean-René LeGlehen) and crew of N/O Suroit (CIRCEE survey, 2013; doi 10.17600/13020060) and also colleagues T. Garlan and Y. Le Faou (SHOM), S. Zaragosi and E. Kong (Univ. Bordeaux) participating to campaign and discussions. Marie Guilcher provided precious analytical support. Funding for this study was provided from the European Union's Seventh Framework Programme (FP7/2007-2013) under grant agreement n 603839 (Project ASTARTE - Assessment, Strategy and Risk Reduction for Tsunamis in Europe) and the INSU-CNRS project Artemis for ${ }^{14} \mathrm{C}$ dating. We thank the editor, Peter Talling and the reviewers, Hugo Pouderoux and Mike Clare, for their constructive and helpful comments.

\section{References}

Ambraseys, N., Melville, C., Adams, R., 1994. The Seismicity of Egypt, Arabia and the Red Sea. Cambrige Univsersity Press, Cambridge. 
Ambraseys, N.N., 1962. Data for the investigation of the seismic sea-waves in the eastern Mediterranean. Bulletin of the Seismological Society of America 52, 895-913

Antonioli, F., Ferranti, L., Lambeck, K., Kershaw, S., Verrubbi, V., Dai Pra, G., 2006. Late Pleistocene to Holocene record of changing uplift rates in southern Calabria and northeastern Sicily (southern Italy, Central Mediterranean Sea). Tectonophysics 422, 2340.

Boschi, E., Guidoboni, E., Ferrari, G., Mariotti, D., Valensise, G., Gasperini, P., 2000. Catalogue of strong Italian earthquakes from 461 B.C. to 1997. Ann. Geofis 43, 609-868.

Bouma, A.H., 1962. Sedimentology of some flysch deposits, Amsterdam, Elsevier.

Bouma, A.H., 1987. Megaturbidite: an acceptable term? Geo-Marine Letters 7, 63-67.

Bourget, J., Zaragosi, S., Rodriguez, M., Fournier, M., Garlan, T., Chamot-Rooke, N., 2013.

Late Quaternary megaturbidites of the Indus Fan: Origin and stratigraphic significance. Marine Geology 336, 10-23.

Camerlenghi, A., Urgeles, R., Fantoni, L., 2010. A Database on Submarine Landslides of the Mediterranean Sea, Sumarine Mass Movements ant their consequences, 28, 503-513.

Catalano, R., Doglioni, C., Merlini, S., 2001. On the Mesozoic lonian Basin. Geophys. J. Int. $144,49-64$.

Cita, M.B., Aloisi, G., 2000. Deep-sea tsunami deposits triggered by the explosion of Santorini (3500 y BP), eastern Mediterranean. Sedimentary Geology 135, 181-203.

Cita, M.B., Camerlenghi, A., Kastens, K.A., McCoy, F.W., 1984. New findings of Bronze Age homogenites in the Ionian Sea: geodynamic implications for the mediterranean. Marine Geology 55, 47-62.

Cita, M.B., Camerlenghi, A., Rimoldi, B., 1996. Deep-sea tsunami deposits in the eastern Mediterranean: new evidence and depositional models. Sedimentary Geology 104, 155173.

D'Agostino, N., Avallone, A., Cheloni, D., D'Anastasio, E., Mantenuto, S., Selvaggi, G., 2008. Active tectonics of the Adriatic region from GPS and earthquake slip vectors. Journal of Geophysical Research 113, B12413, DOI: 10.1029/2008jb005860. 
De Martini, P.M., Barbano, M.S., Pantosti, D., Smedile, A., Pirrotta, C., Del Carlo, P., Pinzi, S., 2012. Geological evidence for paleotsunamis along eastern Sicily (Italy): an overview. Natural Hazards and Earth System Science 12, 2569-2580.

De Martini, P.M., Barbano, M.S., Smedile, A., Gerardi, F., Pantosti, D., Del Carlo, P., Pirrotta, C., 2010. A unique 4000 year long geological record of multiple tsunami inundations in the Augusta Bay (eastern Sicily, Italy). Marine Geology 276, 42-57.

Finetti, I., 1982. Structure, stratigraphy and evolution of central mediterranean. Bollettino di Geofisica Teorica et Applicata 24, 247-312.

Friedrich, W.L., Kromer, B., Friedrich, M., Heinemeier, J., Pfeiffer, T., Talamo, S., 2006. Santorini eruption radiocarbon dated to 1627-1600 B.C. Science 312, 548.

Gallais, F., Gutscher, M.-A., Klaeschen, D., Graindorge, D., 2012. Two-stage growth of the Calabrian accretionary wedge in the Ionian Sea (Central Mediterranean): Constraints from depth-migrated multichannel seismic data. Marine Geology 326-328, 28-45.

Gasperini, P., Camassi, R., Mirto, C., Stucci, M. and gruppo di lavoro CPTI, 2004. Catalogo parametrico dei terremoti italiani, versione 2004 (CPTI04), INGV, Bologna. http://emidius.mi.ingv.it/CPTI04/

Gutscher, M.-A., Dominguez, S., Mercier de Lepinay, B., Pinheiro, L., Gallais, F., Babonneau, N., Cattaneo, A., LeFaou, Y., Barreca, G., Micallef, A., Rovere, M., 2015. Tectonic expression of an active slab-tear from high-resolution seismic and bathymetric data offshore Sicily (Ionian Sea). Tectonics, 34, DOI: 10.1002/2015TC003898

Hieke, W., 1984. A thick holocene homogenite from the Ionian Abyssal Plain (eastern mediterranean). Marine Geology 55, 63-78.

Hieke, W., 2000. Transparent layers in seismic reflection records from the central Ionian Sea (Mediterranean) - evidence for repeated catastrophic turbidite sedimentation during the Quaternary. Sedimentary Geology 135, 89-98.

Hieke, W., Hirschleber, H.B., Dehghani, G.A., 2003. The Ionian Abyssal Plain (central Mediterranean Sea): Morphology, subbottom structures and geodynamic history - an inventory. Marine Geophysical Researches 24, 279-310. 
Hieke, W., Werner, F., 2000. The Augias megaturbidite in the central Ionian Sea (central Mediterranean)and its relation to the Holocene Santorini event Sedimentary Geology 135, 205-218.

Hinz, K., 1974. Results of seismic refraction and seismic reflexion measurements in the Ionian Sea, Geol. Jahrb., Reihe E, 33-65.

Insinga, D.D., Tamburrino, S., Lirer, F., Vezzoli, L., Barra, M., De Lange, G.J., Tiepolo, M., Vallefuoco, M., Mazzola, S., Sprovieri, M., 2014. Tephrochronology of the astronomicallytuned KC01B deep-sea core, Ionian Sea: insights into the explosive activity of the Central Mediterranean area during the last 200 ka. Quaternary Science Reviews 85, 63-84.

IOC - Intergovernmental Oceanographic Commission, 1981, International Bathymetric Chart of the Mediterranean, 1: 1,000,000 (Lat. $38^{\circ}$ ). 10 sheets. Head Department of Navigation Oceanogr., Leningrad.

Kastens, K.A., Cita, M.B., 1981. Tsunami-induced sediment transport in the abyssal Mediterranean Sea. Geological Society of America Bulletin, Part. I 92, 845-857.

Keller, J., Ryan, W.B.F., Ninkovich, D., Altherr, R., 1978. Explosive volcanic activity in the Mediterranean over the past $200,000 \mathrm{yr}$ as recorded in deep-sea sediments. Geological Society of America Bulletin 89, 591-604.

Kidd, R.B., Cita, M.B., Ryan, W.B.F., 1978. Stratigraphy of eastern Mediterranean sapropel sequences recovered during DSDP Leg 42A and their paleoenvironmental significance. Initial Reports of the Deep-Sea Drilling Project 42A, 421-443.

Loubrieu, B., Mascle, G., and Medimap group (19 authors), 2007. Morpho-bathymetry of the Mediterranean Sea, Ifremer - CIESM.

Lowe, J.J., Blockley, S., Trincardi, F., Asioli, A., Cattaneo, A., Matthews, I.P., Pollard, M., Wulf, S., 2007. Age modelling of late Quaternary marine sequences in the Adriatic: Towards improved precision and accuracy using volcanic event stratigraphy. Continental Shelf Research 27, 560-582. 
Manning, S.W., Ramsey, C.B., Kutschera, W., Higham, T., Kromer, B., Steier, P., Wild, E.M., 2006. Chronology for the Aegean Late Bronze Age 1700-1400 B.C. Science 312, 565569.

Minelli, L., Faccenna, C., 2010. Evolution of the Calabrian accretionary wedge (central Mediterranean). Tectonics 29, TC4004.

Mulder, T., Zaragosi, S., Razin, P., Grelaud, C., Lanfumey, V., Bavoil, F., 2009. A new conceptual model for the deposition process of homogenite: Application to a cretaceous megaturbidite of the western Pyrenees (Basque region, SW France). Sedimentary Geology 222, 263-273.

Ochoa, J., Wolak, J., Gardner, M.H., 2013. Recognition criteria for distinguishing between hemipelagic and pelagic mudrocks in the characterization of deep-water reservoir heterogeneity. AAPG bulletin, 97(10), 1785-1803

Papadopoulos, G.A., Daskalaki, A., Fokaefs, A., Giraleas, N., 2010. Tsunami hazard in the Eastern Mediterranean Sea: strong earthquakes and tsunamis in the West Hellenic Arc and Trench System. J. Earthq. Tsunami 4, 145-179.

Pirazzoli, P., Laborel, J., Stiros, S.C., 1996. Earthquake clustering in the Eastern Mediterranean during historical times. Journal of Geophysical Research 101, 6083-6097.

Pirazzoli, P., Thommeret, J., Thommeret, Y., Laborel, J., Montagionni, L., 1982. Crustal block movements from Holocene shorelines: Crete and Antikythira (Greece). Tectonophysics 68, 27-43.

Polonia, A., Bonatti, E., Camerlenghi, A., Lucchi, R.G., Panieri, G., Gasperini, L., 2013. Mediterranean megaturbidite triggered by the AD 365 Crete earthquake and tsunami. Sci Rep 3, 1285; DOI:10.1038/srep01285

Polonia, A., Torelli, L., Mussoni, P., Gasperini, L., Artoni, A., Klaeschen, D., 2011. The Calabrian Arc subduction complex in the Ionian Sea: Regional architecture, active deformation, and seismic hazard. Tectonics 30, TC5018. 
Pope, E.L., Talling, P.J., Urlaub, M., Hunt, J.E., Clare, M.A., Challenor, P., 2015. Are large submarine landslides temporally random or do uncertainties in available age constraints make it impossible to tell? Marine Geology 369, 19-33.

Reeder, M.S., Rothwell, R.G., Stow, D.A.V., 2000. Influence of sea level and basin physiography on emplacement of the late Pleistocene Herodotus Basin Megaturbidite, SE Mediterranean Sea. Marine and Petroleum Geology 17, 199-218.

Reimer, P.J., Baillie, M.G.L., Bard, E., Bayliss, A., Beck, J.W., Blackwell, P.G., Bronk Ramsey, C., Buck, C.E., Burr, G.S., Edwards, R.L., Friedrich, M., Grootes, P.M., Guilderson, T.P., Hajdas, I., Heaton, T.J., Hogg, A.G., Hughen, K.A., Kaiser, K.F., Kromer, B., McCormac, F.G., Manning, S.W., Reimer, R.W., Richards, D.A., Southon, J.R., Talamo, S., Turney, C.S.M., van der Plicht, J., Weyhenmeyer, C.E., 2009. IntCal09 and Marine09 radiocarbon age calibration curves, 0-50,000 years cal BP. Radiocarbon $51,1111-1150$.

Rothwell, R.G., Thomson, J., Kähler, G., 1998. Low-sea-level emplacement of a very large Late Pleistocene "megaturbidite" in the western Mediterranean Sea. Nature 392, 377380.

Rothwell, R.G. (ed.) and the Marion Dufresne Cruise 81 Scientific Party, 1995. Marion Dufresne Cruise 81: Mediterranean Giant Piston Coring Transect. Cruise Report (MAST II PALEOFLUX Programme), p. 117 pp.

Roure, F., Casero, P., Addoum, B., 2012. Alpine inversion of the North African margin and delamination of its continental lithosphere. Tectonics 31,TC3006.

Ryan, W.B.F., Heezen, B.C., 1965. Ionian Sea Submarine Canyons and the 1908 Messina Turbidity Current. Geological Society of America Bulletin 76, 915-932.

Shaw, B., Ambraseys, N.N., England, P.C., Floyd, M.A., Gorman, G.J., Higham, T.F.G., Jackson, J.A., Nocquet, J.M., Pain, C.C., Piggott, M.D., 2008. Eastern Mediterranean tectonics and tsunami hazard inferred from the AD 365 earthquake. Nature Geoscience 1, 268-276. 
Smedile, A., De Martini, P.M., Pantosti, D., 2012. Combining inland and offshore paleotsunamis evidence: the Augusta Bay (eastern Sicily, Italy) case study. Natural Hazards and Earth System Science 12, 2557-2567.

Smedile, A., De Martini, P.M., Pantosti, D., Bellucci, L., Del Carlo, P., Gasperini, L., Pirrotta, C., Polonia, A., Boschi, E., 2011. Possible tsunami signatures from an integrated study in the Augusta Bay offshore (Eastern Sicily-Italy). Marine Geology 281, 1-13.

Stiros, S.C., 2001. The AD 365 Crete earthquake and possible seismic clustering during the fourth to sixth centuries $A D$ in the Eastern Mediterranean: a review of historical and archaeological data. Journal of Structural Geology 23, 545-562.

Thorarinsson, S., 1954. The eruption of Hekla, 1947-48II, 3, The tephra-fall from Hekla, March 29th, 1947. Visindafélag Íslendinga, 1-3.

Tinti, S., Maramai, A., Graziani, L., 2004. The new catalogue of Italian Tsunamis. Natural Hazards 33, 439-465.

Urlaub, M., Talling, P.J., Masson, D.G., 2013. Timing and frequency of large submarine landslides: implications for understanding triggers and future geohazard. Quaternary Science Reviews 72, 63-82.

Vigliotti, L., 2008. Comment on "Lost tsunami” by Maria Teresa Pareschi et al. Geophysical Research Letters 35, L02608.

Westaway, R., 1993. Quaternary uplift of southern Italy. Journal of Geophysical Research 98, B12, 21, 741-21, 772.

Wynn, R.B., Talling, P.J., Masson, D.G., Stevenson, C.J., Cronin, B.T., Le Bas, T.P., 2010. Investigating the timing, processes and deposits of the one of the world's largest submarine gravity flows: the "Bed 5 event" off northwest africa. Advances in Natural and Technological Hazards Research 28, 463-474.

Wynn, R.B., Weaver, P.P.E., Ercilla, G., Stow, D.A.V., Masson, D.G., 2000. Sedimentary processes in the Selvage sediment-wave field, NE Atlantic: new insights into the formation of sediment waves by turbidity currents. Sedimentology 47, 1181-1197. 


\section{TABLE AND FIGURE CAPTIONS}

\section{TABLES}

Table 1. Definition of different facies observed in the Central and Eastern Mediterranean, based on description of cores sampled in Ionian Sea.

Table 2. Name and location of Kullenberg piston cores (latitude and longitude in decimals degrees, water depth and recovered core length).

Table 3. AMS radiocarbon dates used to construct the age model. This age were calibrated with CALIB REV 7.0.4.

Table 4. Age and thickness of Augias deposit at distinct locations in the study area

Table 5: Summary of information on Augias basal interval according to facies with location, geochemical, composition and sedimentary processes and associated with origin of sediment.

\section{FIGURES}

Figure 1. Structural map of the Calabrian accretionary wedge derived from the interpretation of seismic data (Polonia et al., 2011; Gallais et al., 2012). Bathymetric data compiled from CIRCEE data, RV Meteor data (M86 and M111 - Dionysus), EMODnet data, SHOM data (French Hydrographic Service), MediMap data (Loubrieu et al., 2007) and GEBCO. Red points represent the CIRCEE sediment cores used in this study and yellows points are cores (Cita and Aloisi, 2000; Polonia et al., 2011) described in Figure 2. Blue points correspond to the location of cable breaks after the 1908 Messina earthquake and tsunami (Ryan and 
Heezen, 1965). The earthquake epicentres are from the catalogue CPTI04 spanning the time period from 217 B.C. to 2002 AD (Gasperini et al., 2004).

Figure 2. Schematic stratigraphy of recent sedimentary deposits in the Ionian Sea showing the main turbidites, tephras, and sapropel layers as well as the Augias deposit (modified from Cita and Aloisi, 2000; Polonia et al., 2013). The location of these cores is shown in Figure 1 (yellows points).

Figure 3. Map illustrating the distribution of the Augias deposit based on seismic profiles (yellow from Hieke et al, 2000) and on sediment cores described by Cita et al. (1996); Hieke (2000); Polonia et al. (2013) and CIRCEE data. Red stars represent the hypothesised epicentres for the origin of the Augias deposit.

Figure 4. a) Morpho-bathymetric interpretation of the Calabrian accretionary wedge showing: the limit of the Ionian Abyssal Plain (green area), anticlinal ridges (red lines), small basins (black lines), large basins (blue lines), submarine canyons axes (yellow lines), and sediment waves (magenta lines). The black line corresponds to the limit between the Malta escarpment (to east) and the Hyblean platform (to west). (b) Bathymetric profile NW-SE from the Messinia Straits to the Ionian Abyssal Plain crossing the different physiographic domains.

Figure 5. Sedimentological logs and photos of the seven CIRCEE cores used in study. The locations are shown in Figures 1 and 4.

Figure 6. Chirp echosounder profiles showing the Augias deposit as an acoustically transparent layer (CIRCEE data) and the different domains described in Figure 4. 
Figure 7. Sedimentological log of core KCIR-05 with photo, magnetic susceptibility, grain size profiles (percentage of sand and clay), chemical composition ( $\mathrm{Ca} / \mathrm{Ti}$ ratio obtained by XRF core scanner) and microfacies photograph of the coarse fraction (>150 um).

Figure 8. Sedimentological logs of cores KCIR-08, KCIR-09 and KCIR-12 with photos, magnetic susceptibility, grain size profiles (percentage of sand and clay), chemical composition ( $\mathrm{Ca} / \mathrm{Ti}$ ratio obtained by XRF core scanner) and microfacies photographs of the coarse fraction (>150 um).

Figure 9. Sedimentological logs of cores KCIR-10 and KCIR-11 with photos, magnetic susceptibility, grain size profiles (percentage of sand and clay), chemical composition ( $\mathrm{Ca} / \mathrm{Ti}$ ratio obtained by XRF Corescanner) and microfacies photographs of the coarse fraction (>150 um).

Figure 10. Correlation panel showing core photographs, simplified columns of sedimentary facies and grain size spectrum (scale on the right side). Red stars indicate calibrated radiocarbon dates. The Augias deposit is indicated by the grey interval.

Figure 11. Chronological diagram with the time intervals of Augias deposits given by radiocarbon datings in the CIRCEE core data set (radiocarbon dates in red). It is estimated the base of Augias deposit thanks to sedimentation rates and it is considers that the Augias event is generated by the Crete earthquake at $365 \mathrm{AD}$ (in black). This result is compared to data of Polonia et al (2013).

Figure 12. Schematic section of the Ionian Sea showing the location of the three sedimentary facies of the Augias deposits according to the basin physiography and water depth. 
Figure 13. Scenario for the Augias event in four stages: (1) earthquake shaking, (2) tsunami implying re-suspension of sediment and gravity instabilities, (3) concentration of sediment plume in the deep basin, (4) deposition of the homogenite facies by decantation coupled with local gravity processes. 


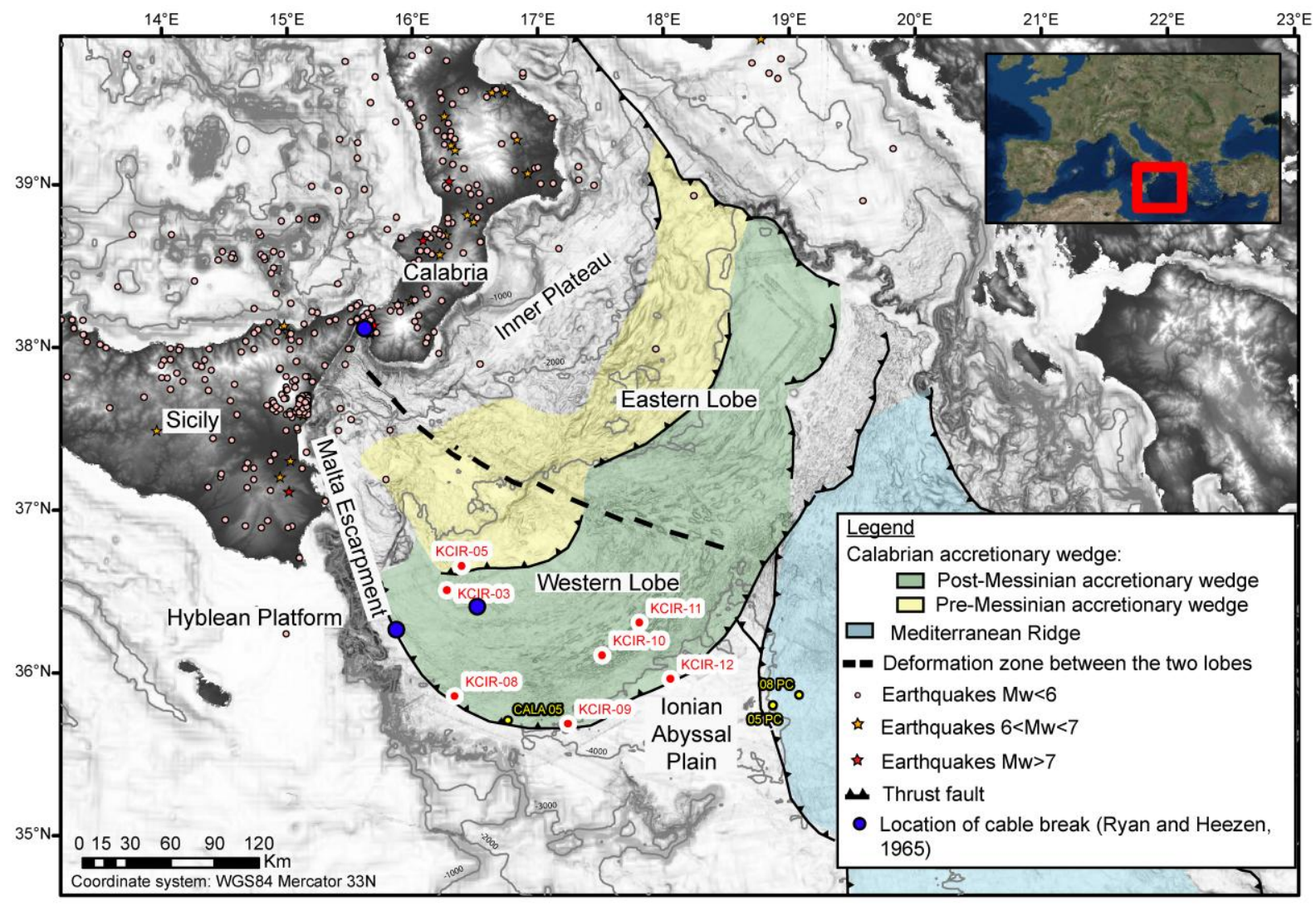

Figure 1 


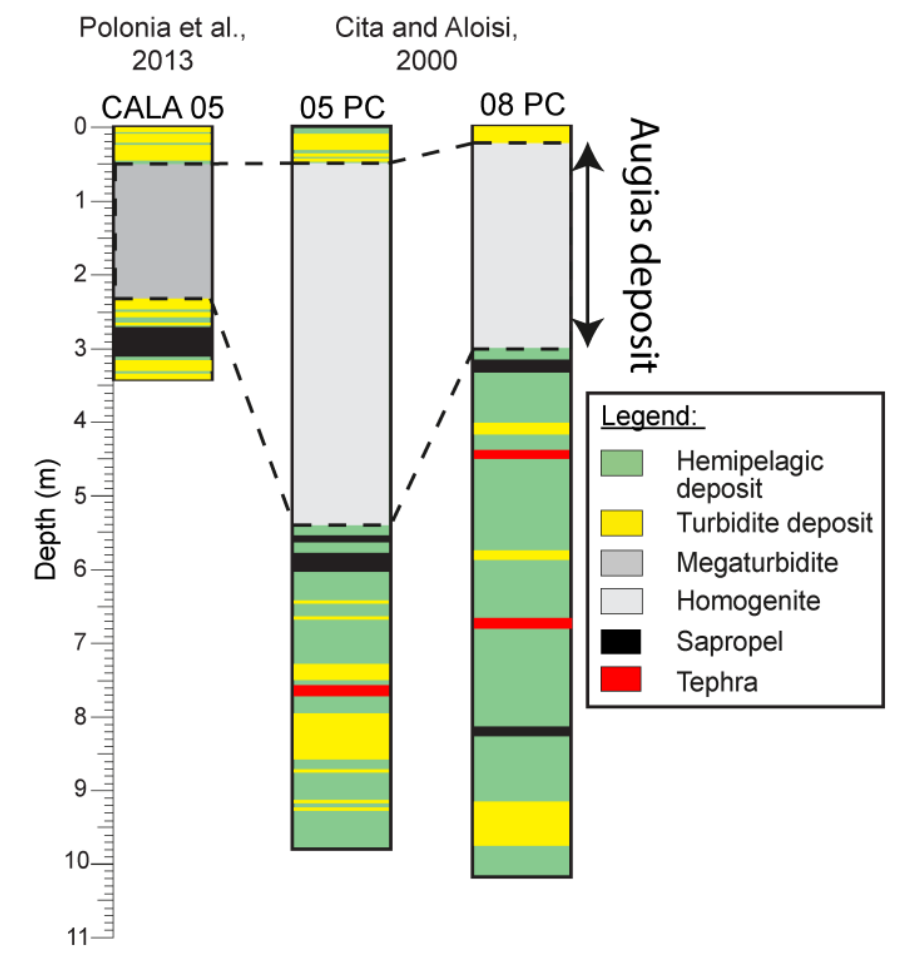

Figure 2 


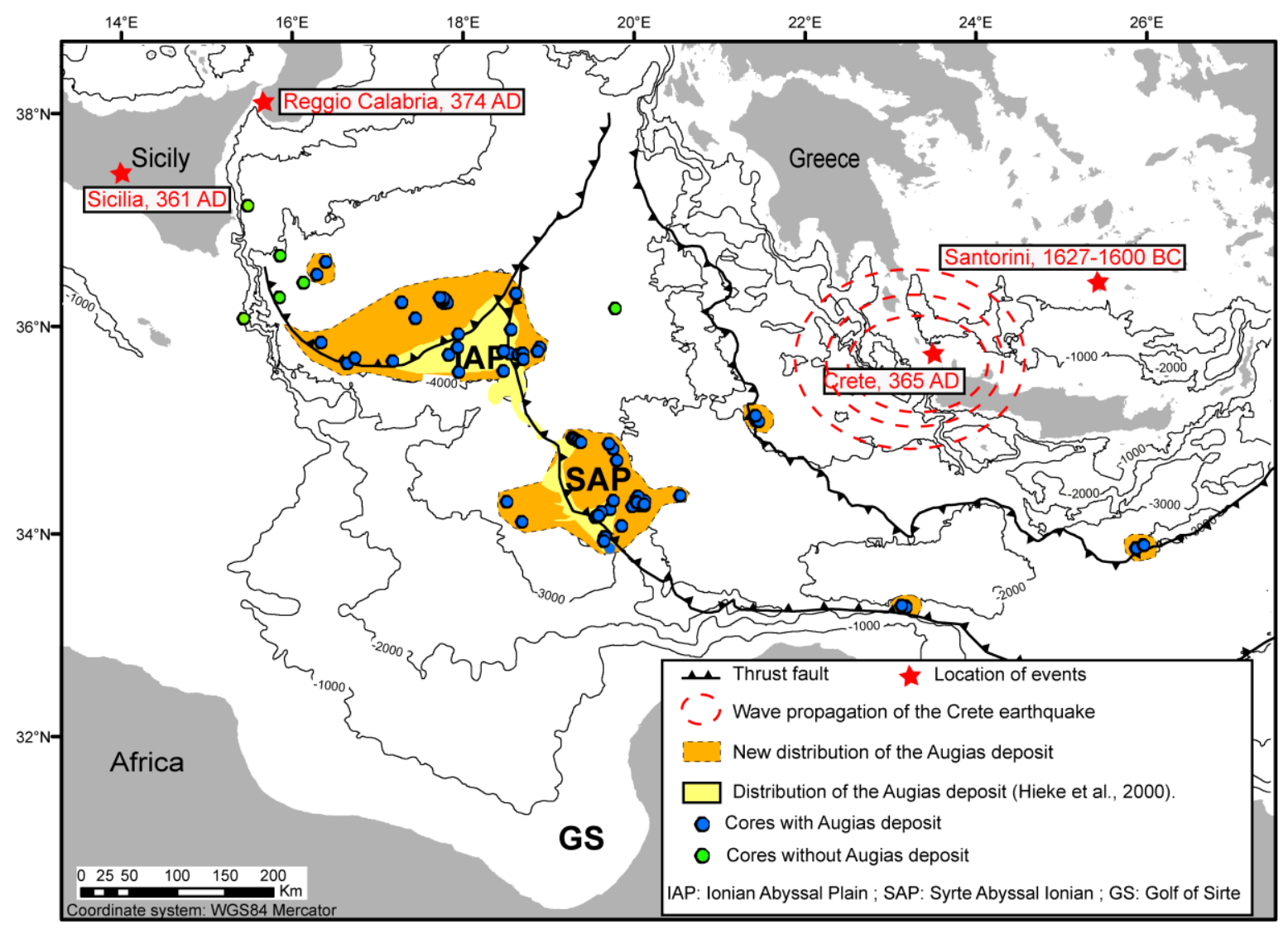

Figure 3 


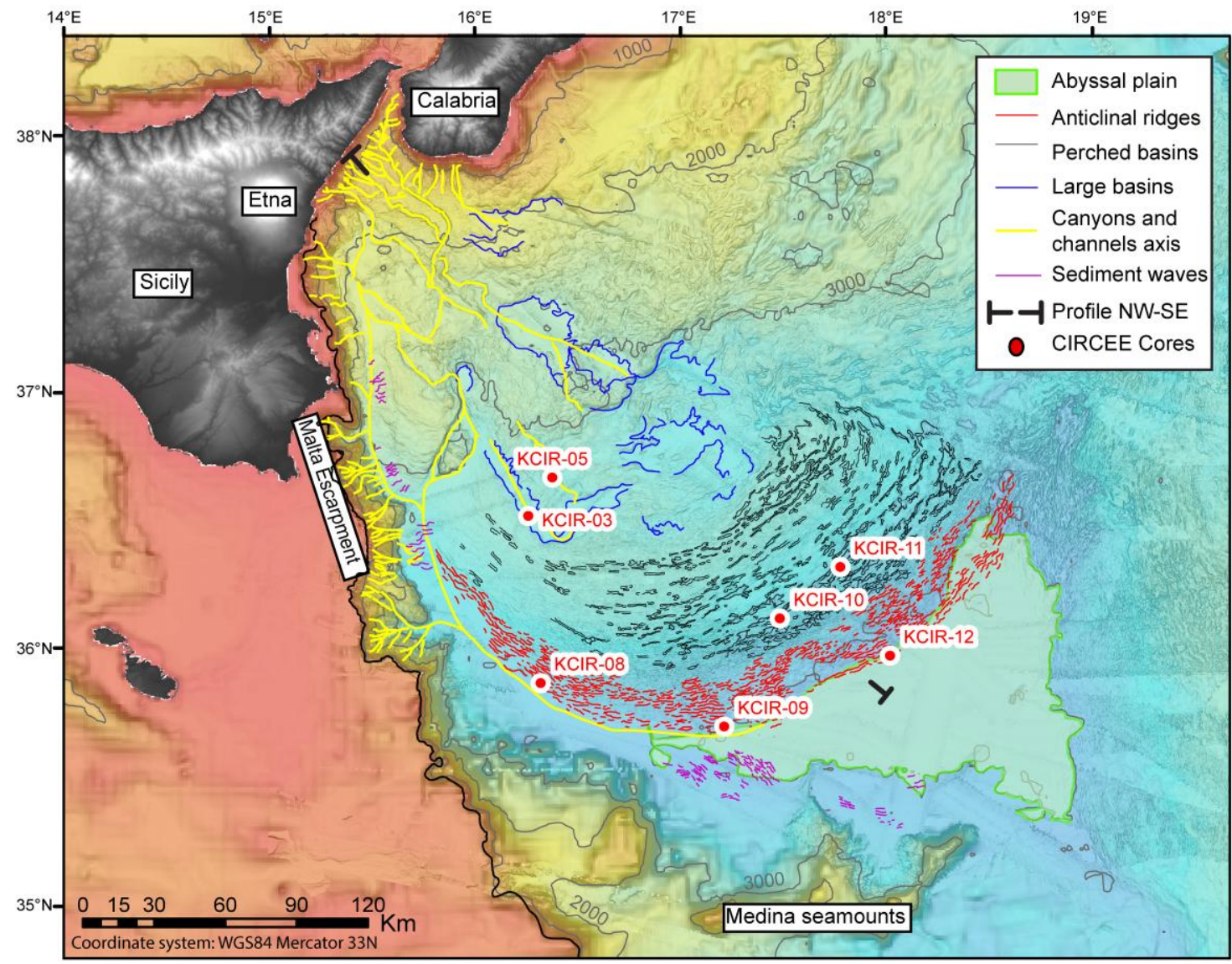

Figure 4a 


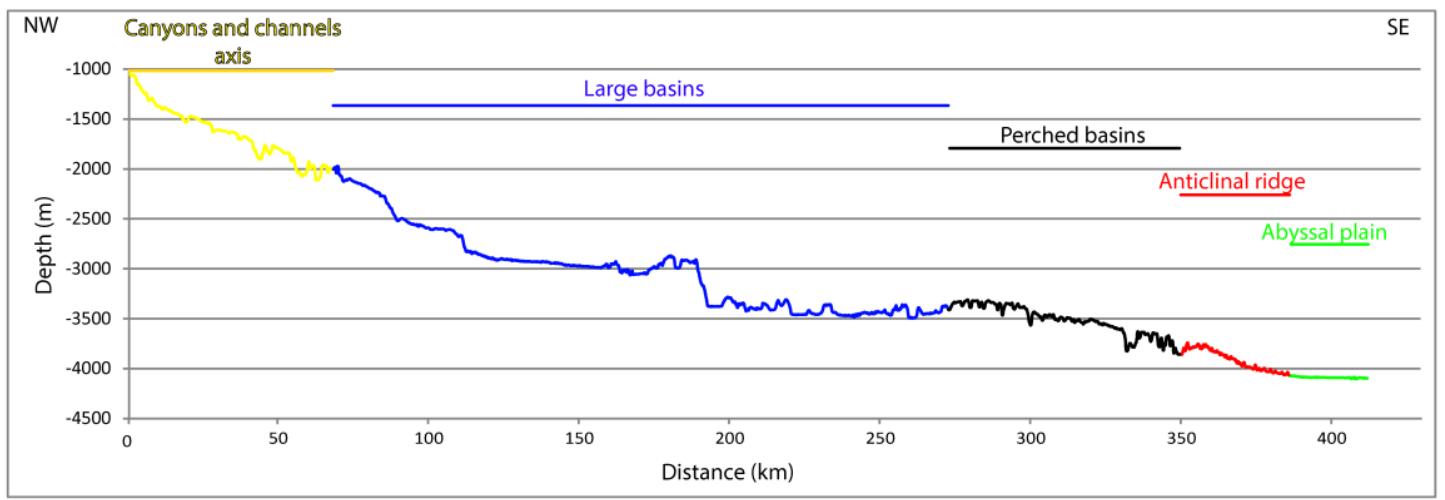

Figure 4b 


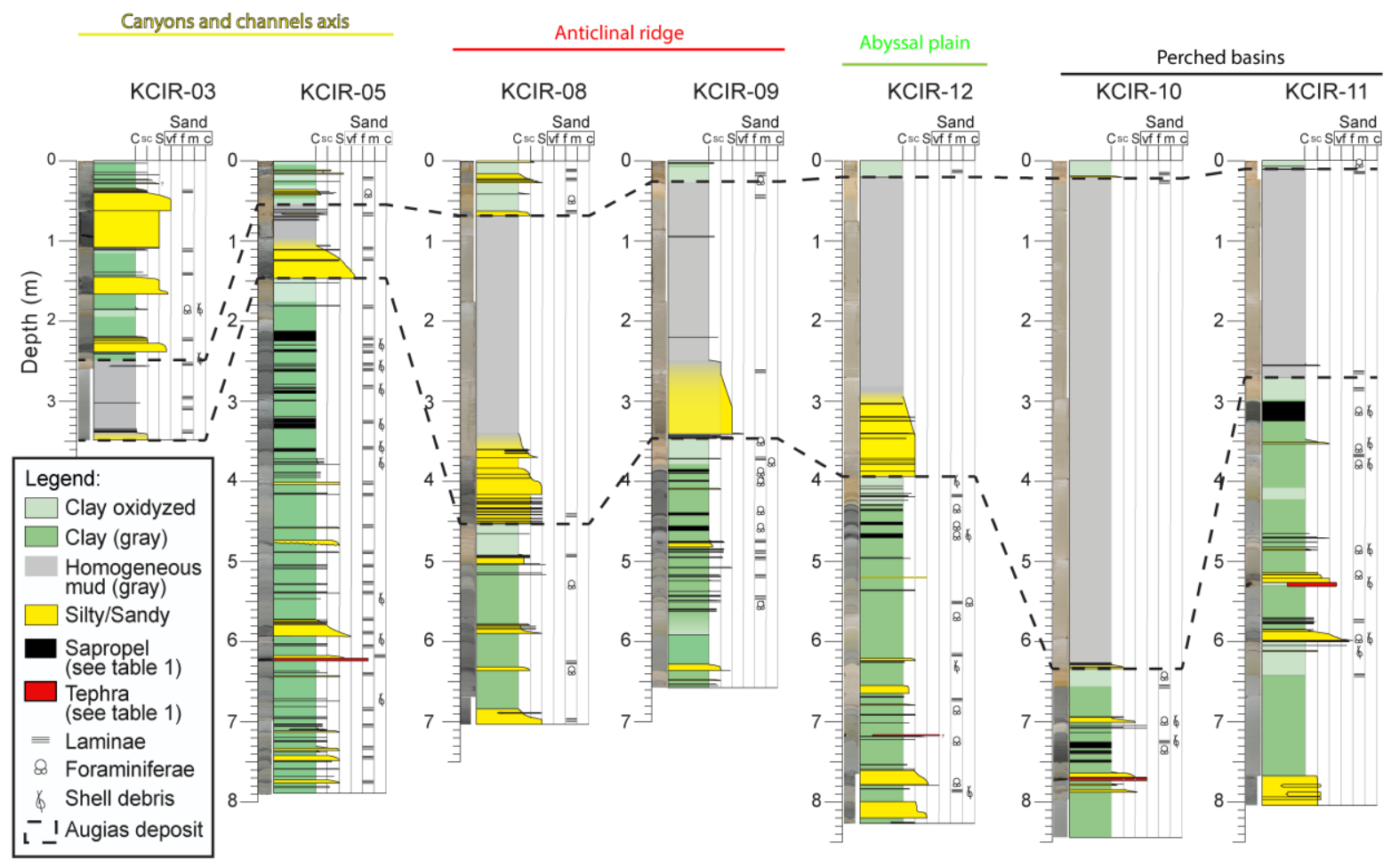

Figure 5 

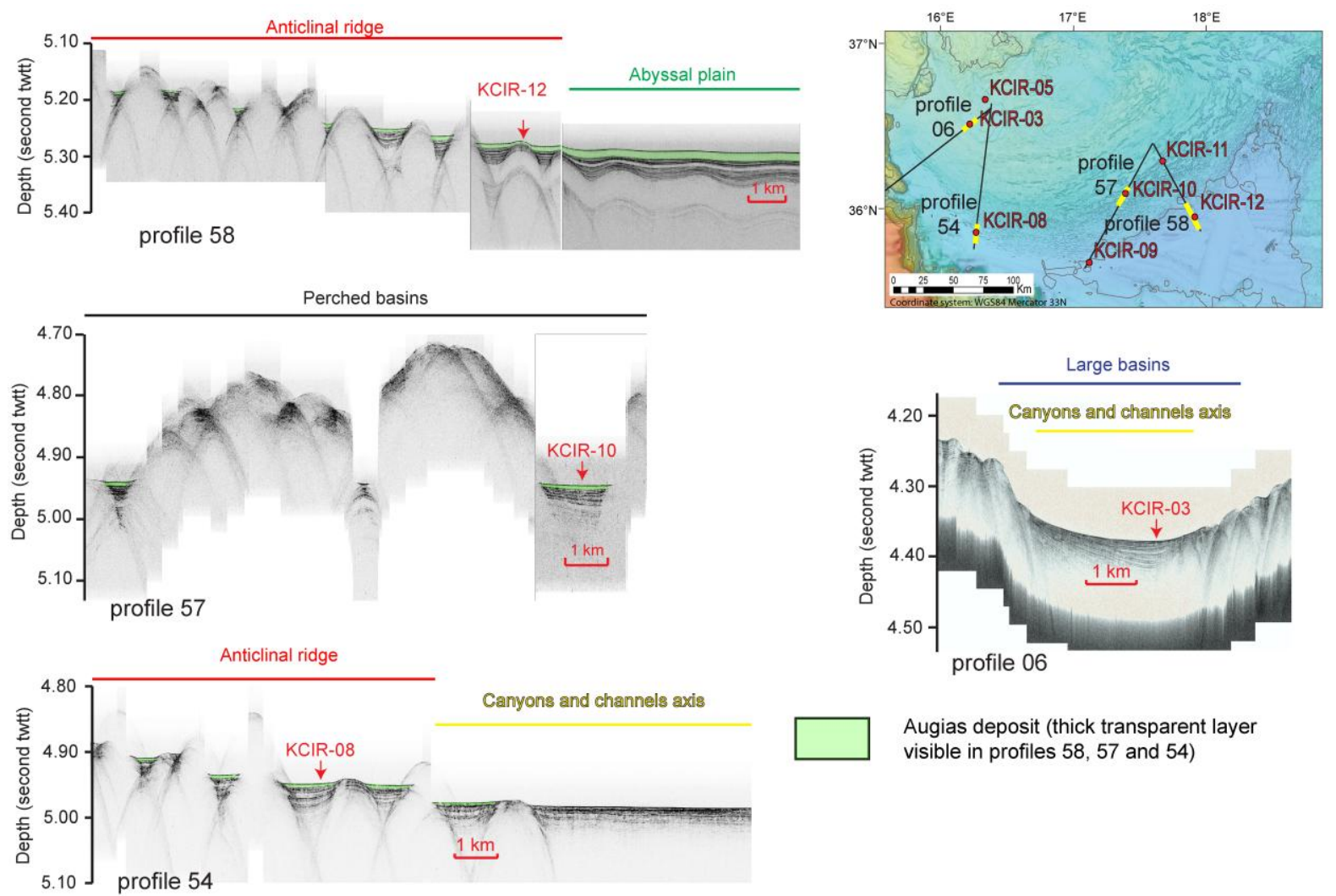

Augias deposit (thick transparent layer visible in profiles 58,57 and 54 )

Figure 6 
Facies 1 "Thick sandy turbidite" KCIR-05
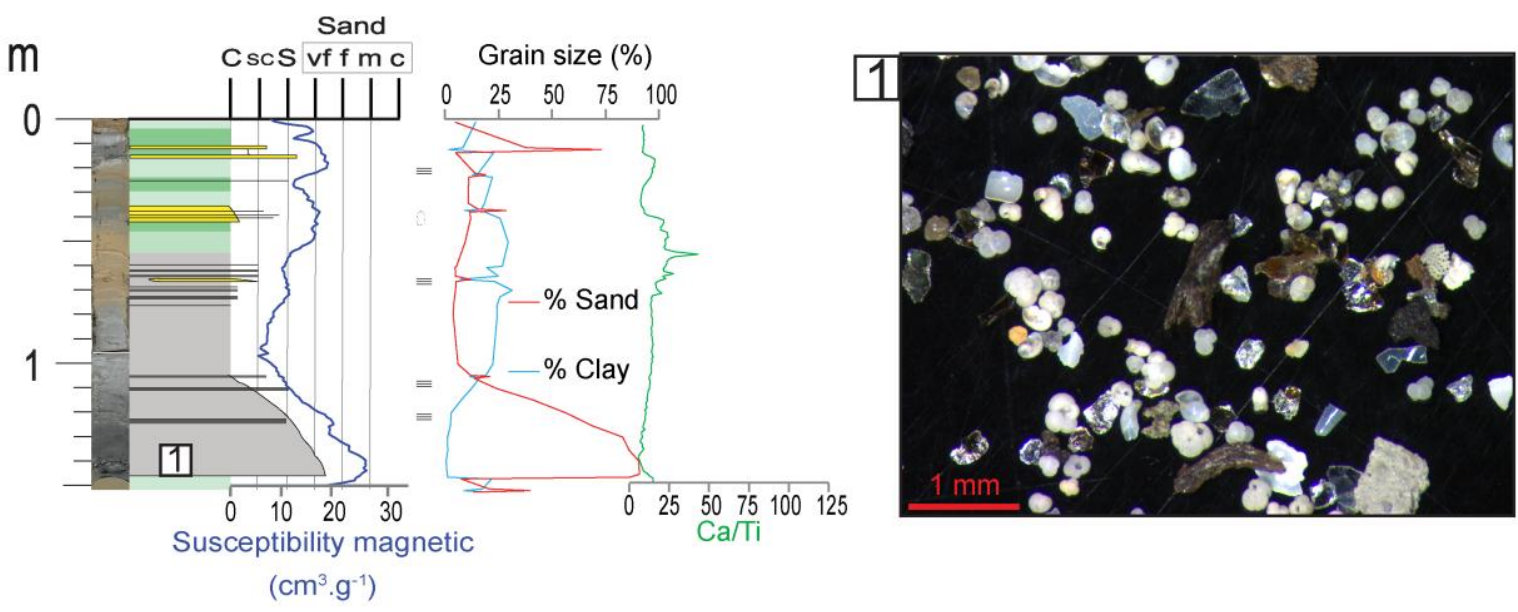

Figure 7 


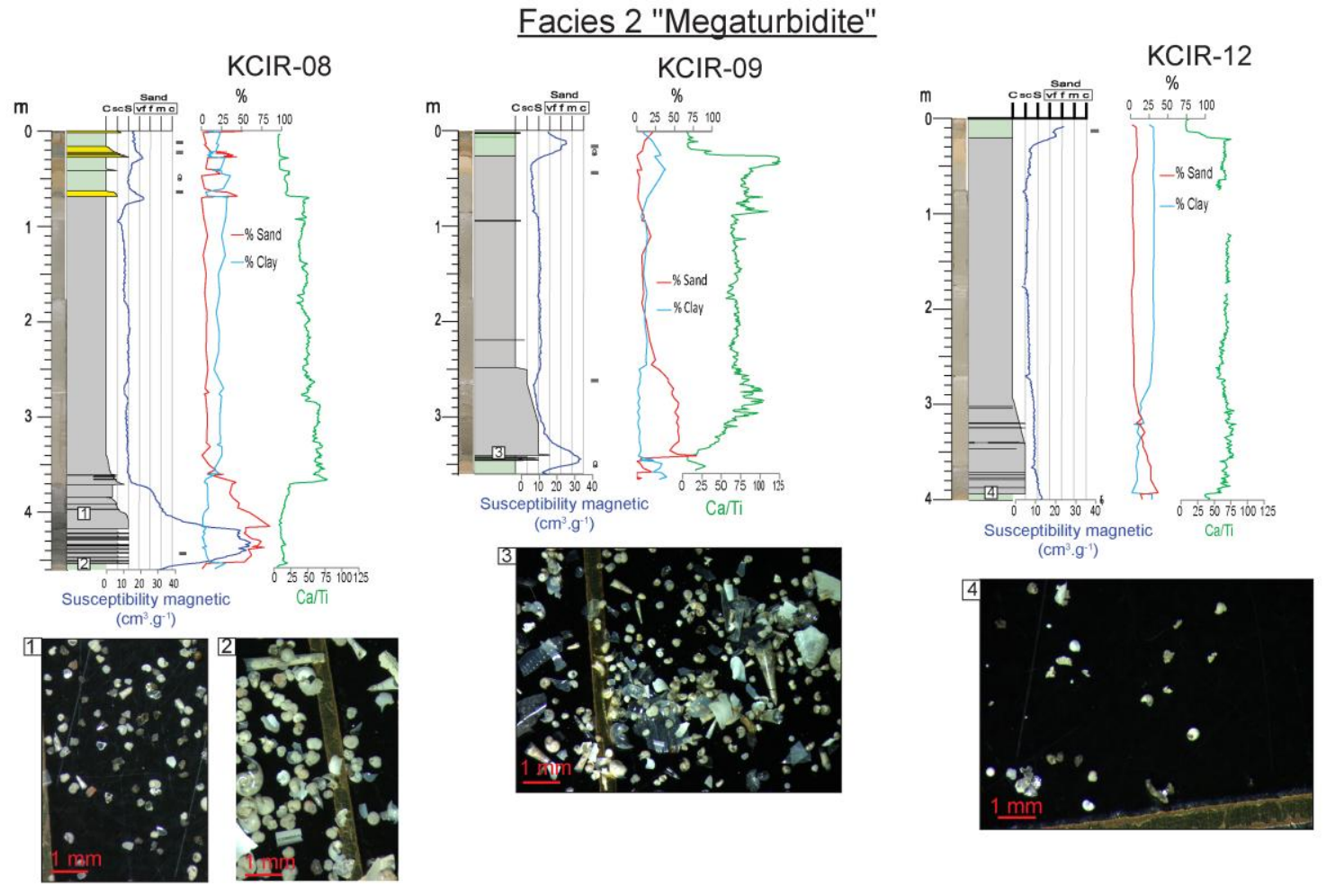

Figure 8 


\section{Facies 3 "Homogenite"}

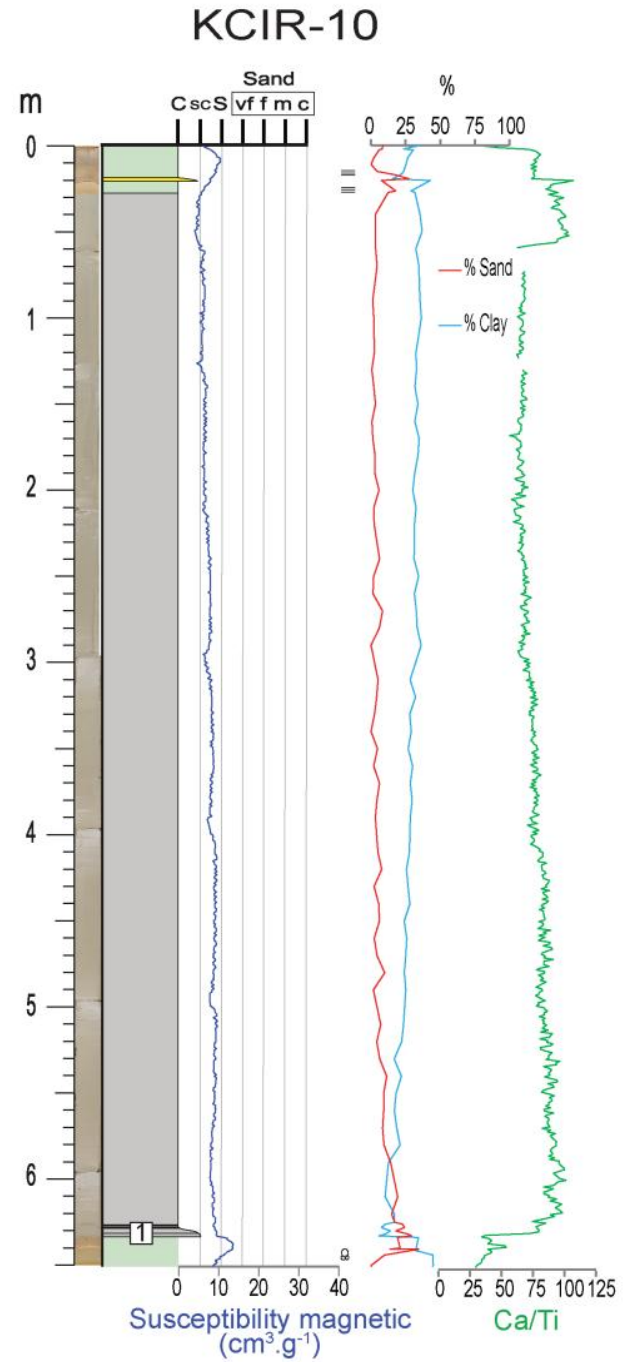

KCIR-11
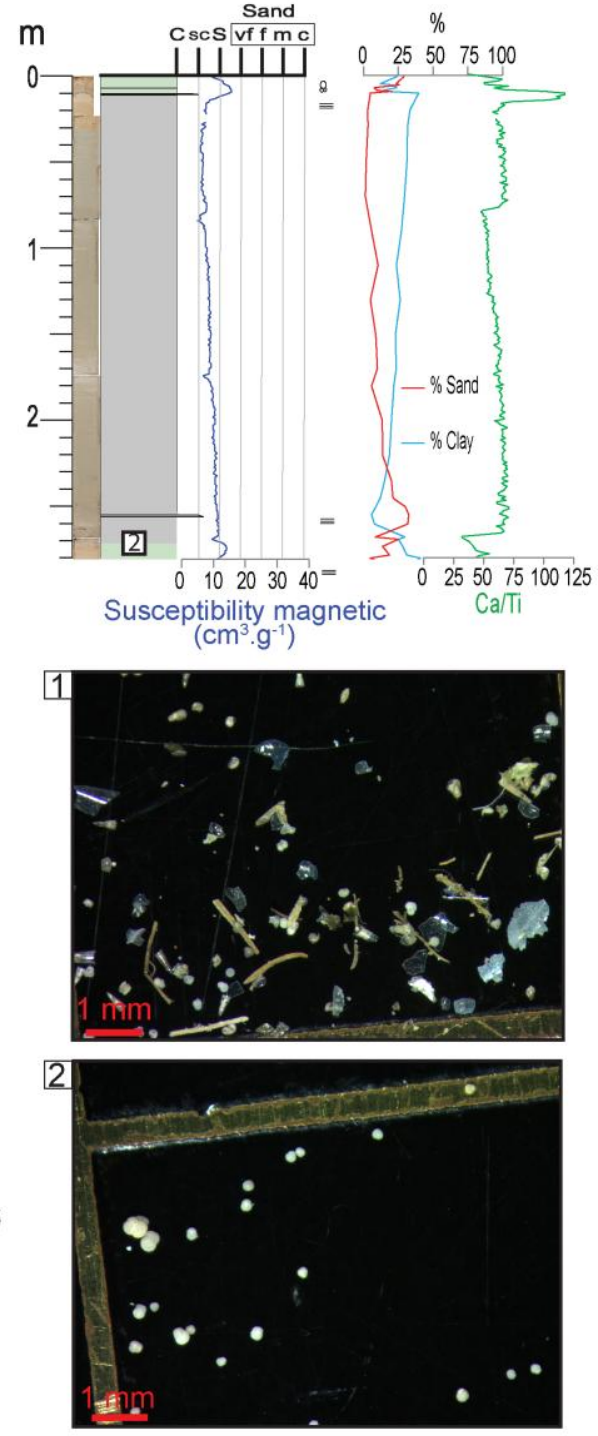

Figure 9 


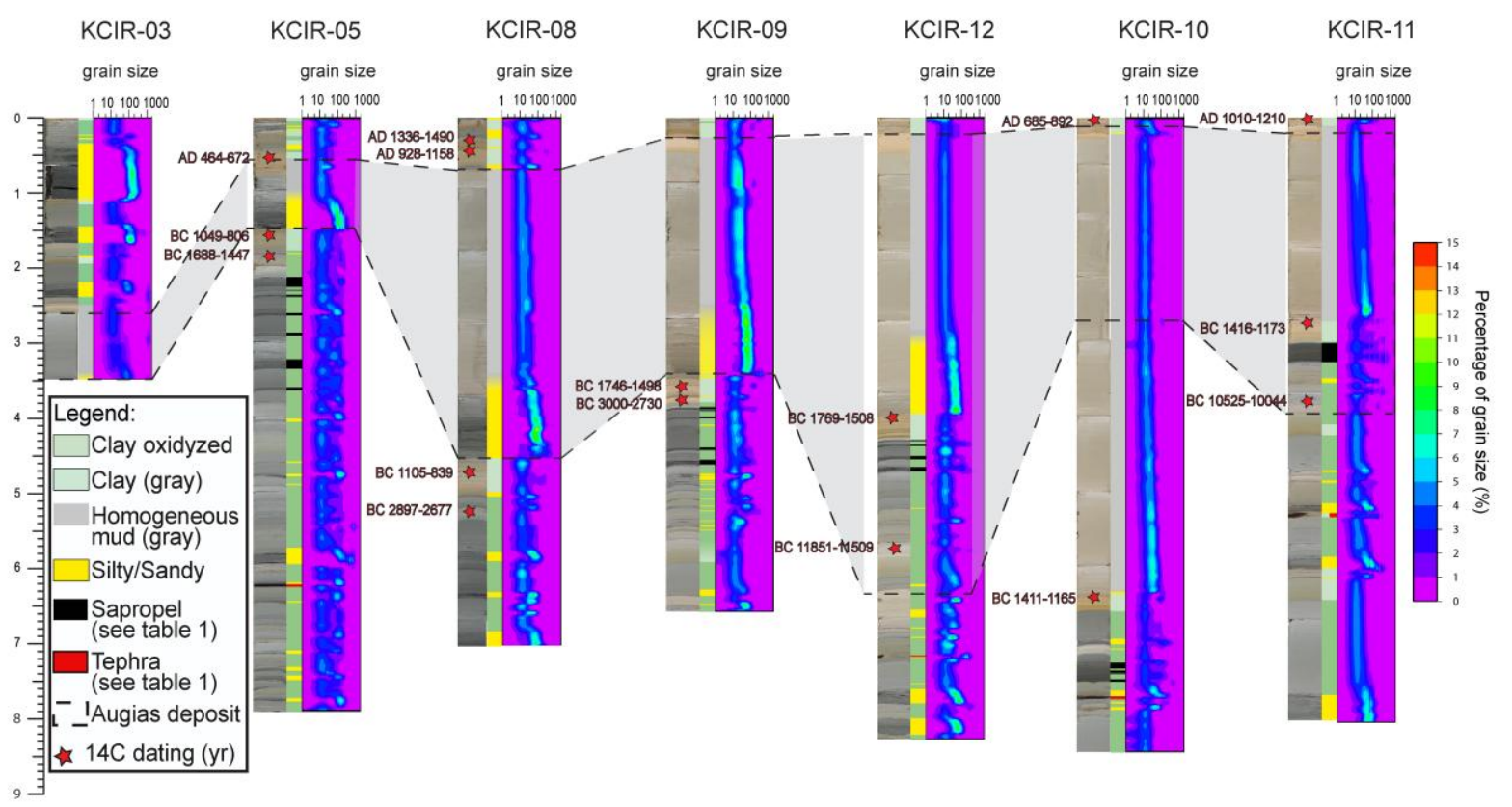

Figure 10 


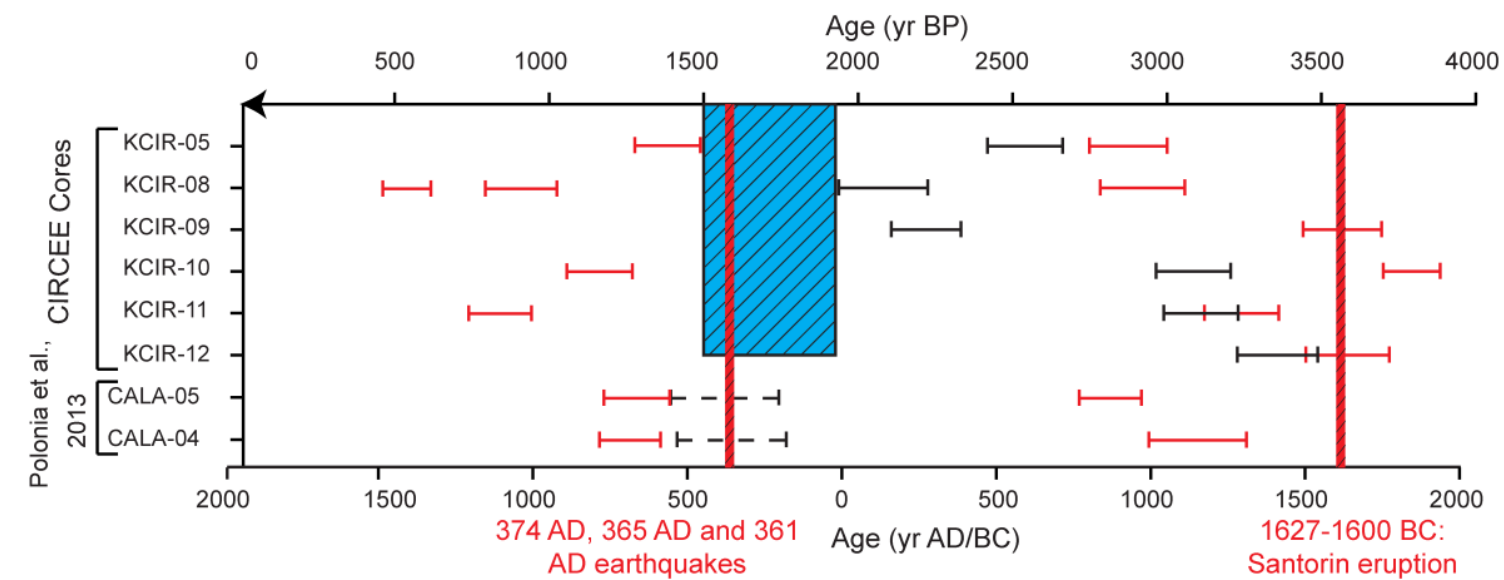

\begin{tabular}{|c|c|c|c|c|c|c|c|}
\hline \multirow{3}{*}{ 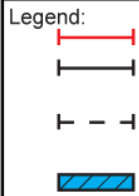 } & \multirow{3}{*}{$\begin{array}{l}\text { Age 14C } \\
\text { Estimated the base of Augias deposit } \\
\text { (without erosion) } \\
\text { Estimated of Augias deposit } \\
\text { (by Polonia et al., 2013) } \\
\text { Age interval of the Augias deposit }\end{array}$} & $\begin{array}{c}\text { Date (yr) } \\
1627-1600 \mathrm{BC} \\
\end{array}$ & $\begin{array}{l}\text { Location } \\
\text { Santorini }\end{array}$ & $\begin{array}{r}\text { Latitude } \\
25.402 \\
\end{array}$ & $\begin{array}{c}\text { Longitude } \\
36.394 \\
\end{array}$ & $\begin{array}{l}\text { Earthquake } \\
\text { Magnitude }\end{array}$ & $\begin{array}{c}\text { Tsunami } \\
\mathrm{X} \\
\end{array}$ \\
\hline & & $374 \mathrm{AD}$ & Reggio Calabria & 38.100 & 15.650 & 6.30 & \\
\hline & & $361 \mathrm{AD}$ & Sicilia & 37.500 & 14.000 & 6.60 & \\
\hline
\end{tabular}

Figure 11 

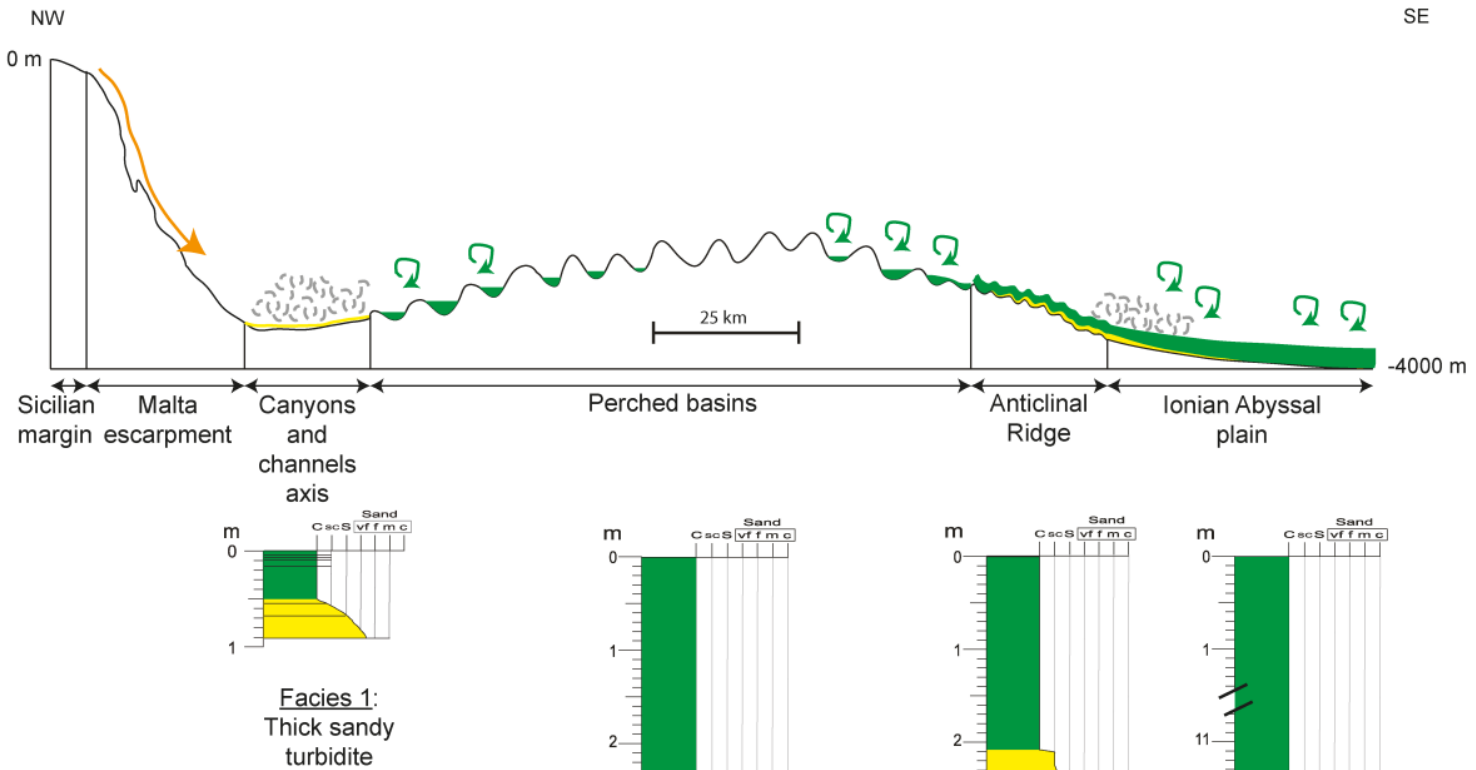

Figure 12
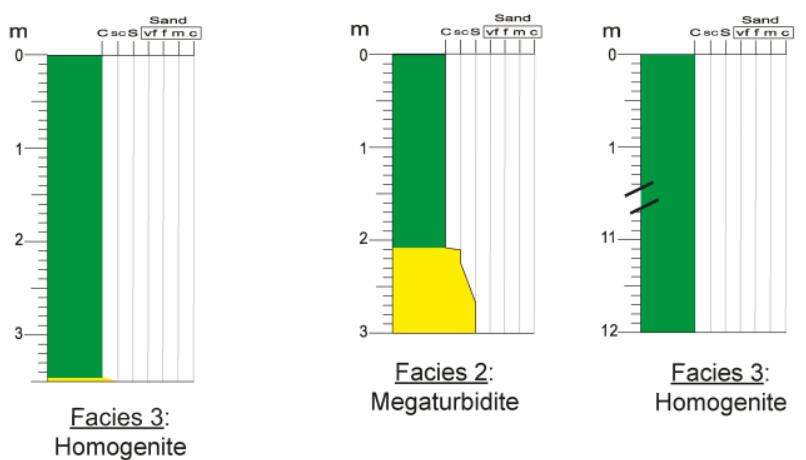

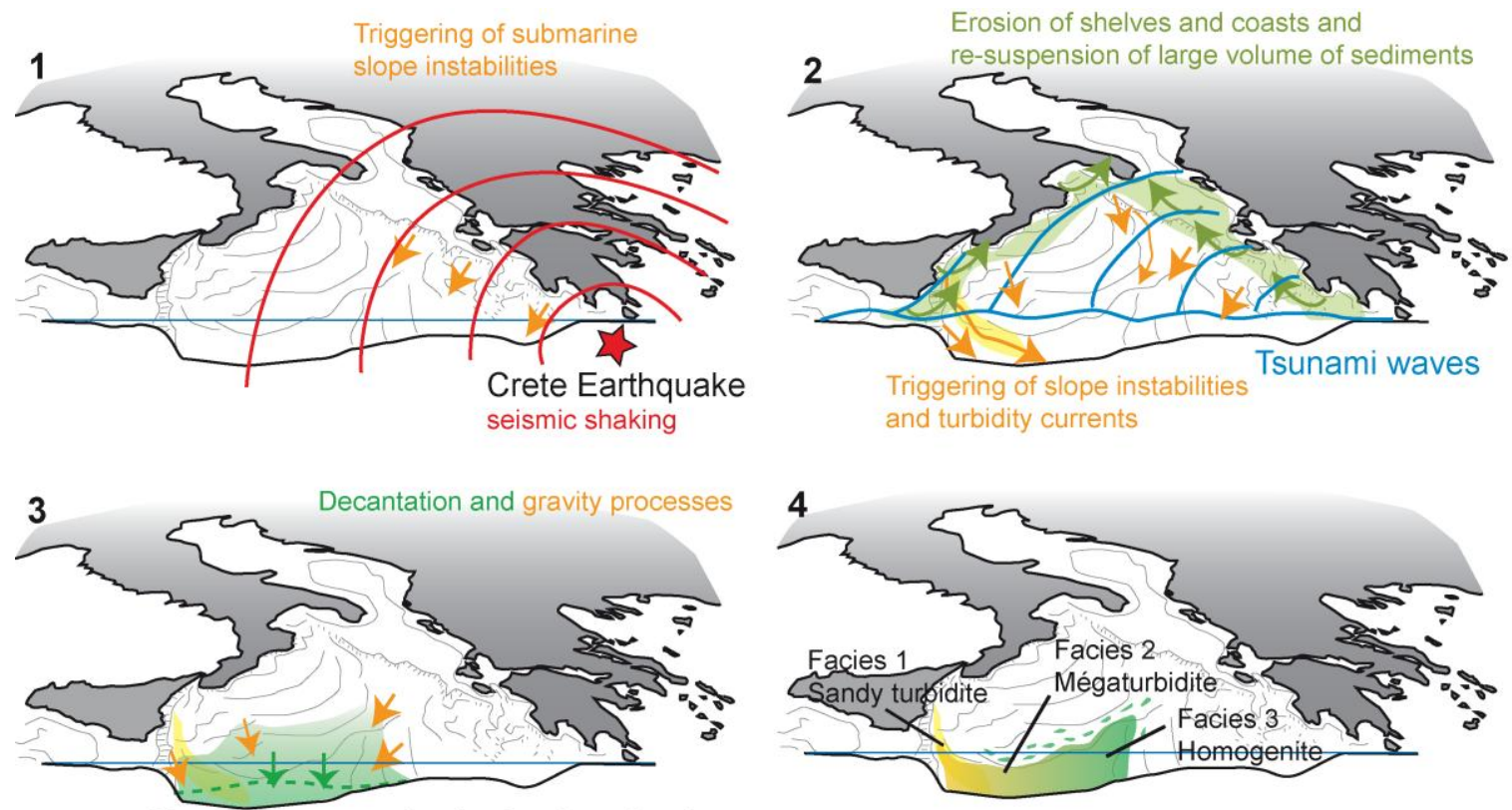

Plume concentration in the deep basin

Final sedimentation of the Augias deposit

Figure 13 


\section{Table 1}

\begin{tabular}{|c|c|c|c|}
\hline Name facies & Definition & Sedimentary processes & References \\
\hline $\begin{array}{l}\text { Hemipelagic } \\
\text { deposit }\end{array}$ & $\begin{array}{l}\text { A type of marine sediment that consists of fine-grained biogenic and terrigenous } \\
\text { material }\end{array}$ & $\begin{array}{l}\text { Accumulation of marine sediment } \\
\text { present in water column }\end{array}$ & Ochoa et al., 2013 \\
\hline Turbidite & $\begin{array}{l}\text { A detrical sediment layer with graded bedding. This is a sequence of five division, } \\
\text { each with its own characteristic sedimentary structure. In the lonian Sea, this } \\
\text { facies is described by a graded layer of coarse sands and silts }\end{array}$ & Deposited by turbidty currents & $\begin{array}{l}\text { Bouma, } 1962 ; \text { Ryan } \\
\text { and Heezen, } 1965\end{array}$ \\
\hline Megaturbidite & $\begin{array}{l}\text { A thick, extensive, relatively homogenous deposit from an exceptionally large } \\
\text { mass flow, consisting of material that is different from the adjacent sedimentary } \\
\text { series and lacking submarine fan geometries }\end{array}$ & $\begin{array}{l}\text { Transported by a gravity-driven, } \\
\text { bottom-hugging, density current or } \\
\text { mass flow }\end{array}$ & Bouma, 1987 \\
\hline Homogenite & $\begin{array}{l}\text { The unit is uniform gray marl, much thicker than most strata found in the } \\
\text { Mediterranean and the grain size decrease regularly from base to top of the unit }\end{array}$ & $\begin{array}{l}\text { The homogenite was emplaced by a } \\
\text { gravity-controlled process }\end{array}$ & Kasten and Cita, 1981 \\
\hline Sapropel & $\begin{array}{l}\text { A black/grey organic carbon-rich layers, with a } 1 \mathrm{~cm} \text { thickness minimum, a total } \\
\text { organic carbon upper } 2 \% \text { and set in open marine pelagic sediment. These } \\
\text { deposits are mainly observed in the east Meditteranean }\end{array}$ & $\begin{array}{l}\text { Accumulation of organic matters by } \\
\text { anoxic conditions in the deep sea }\end{array}$ & Kidd et al., 1978 \\
\hline Tephra & $\begin{array}{l}\text { A volcanic material (pumice orland volcanic glasses) deposited by the fallout of } \\
\text { volcanic particles after a volcanic eruption }\end{array}$ & Fall out after volcanic eruption & Thorarinsson, 1954 \\
\hline
\end{tabular}


Table 2

\begin{tabular}{|ccccc|}
\hline Cores & Lat. $(\mathbf{N})$ & Long. & Depth $(\mathbf{m})$ & Core length $(\mathbf{m})$ \\
\hline KCIR-03 & $36^{\circ} 30.82$ & $16^{\circ} 13.27$ & 3364 & 3.48 \\
\hline KCIR-05 & $36^{\circ} 39.70$ & $16^{\circ} 20.20$ & 3340 & 7.89 \\
\hline KCIR-08 & $35^{\circ} 51.73$ & $16^{\circ} 16.14$ & 3810 & 7.04 \\
\hline KCIR-09 & $35^{\circ} 40.85$ & $17^{\circ} 07.12$ & 3996 & 6.57 \\
\hline KCIR-10 & $36^{\circ} 05.80$ & $17^{\circ} 23.41$ & 3806 & 8.44 \\
\hline KCIR-11 & $36^{\circ} 17.46$ & $17^{\circ} 40.75$ & 3760 & 8.05 \\
\hline KCIR-12 & $35^{\circ} 56.44$ & $17^{\circ} 53.96$ & 4069 & 8.27 \\
\hline
\end{tabular}


Table 3

\begin{tabular}{|c|c|c|c|c|c|}
\hline Cores & Depth (cm) & Species & $\begin{array}{c}\text { 14C age BP } \\
\text { (uncalibrated) }\end{array}$ & $\begin{array}{c}\text { Age Calibrated } \\
\text { BP with } \\
\Delta R=147 \pm 24\end{array}$ & $\begin{array}{c}\text { Age Calibrated } \\
\text { AD/BC with } \\
\Delta R=147 \pm 24\end{array}$ \\
\hline KCIR-05 & $53.2-54$ & $\begin{array}{l}\text { G. Ruber, G. } \\
\text { Sacculifer }\end{array}$ & $1970 \pm 30$ & $1278-1486$ & AD 464-672 \\
\hline KCIR-05 & $157-158.1$ & $\begin{array}{l}\text { G. Ruber, G. } \\
\text { Sacculifer }\end{array}$ & $3250 \pm 30$ & $2755-2998$ & BC 1049-806 \\
\hline KCIR-05 & $180-181.2$ & $\begin{array}{l}\text { G. Ruber, G. } \\
\text { Sacculifer }\end{array}$ & $3770 \pm 30$ & $3396-3637$ & BC 1688-1447 \\
\hline KCIR-08 & $27.4-28.4$ & $\begin{array}{l}\text { G. Ruber, G. } \\
\text { Sacculifer }\end{array}$ & $1060 \pm 30$ & $460-614$ & AD 1336-1490 \\
\hline KCIR-08 & $42-43$ & $\begin{array}{l}\text { G. Ruber, G. } \\
\text { Sacculifer }\end{array}$ & $1515 \pm 30$ & $792-1022$ & AD 928-1158 \\
\hline KCIR-08 & $473.3-474.7$ & $\begin{array}{l}\text { G. Ruber, G. } \\
\text { Sacculifer }\end{array}$ & $3285 \pm 30$ & $2788-3054$ & BC 1105-839 \\
\hline KCIR-08 & $520,5-521,5$ & $\begin{array}{l}\text { G. Ruber, G. } \\
\text { Sacculifer }\end{array}$ & $4700 \pm 30$ & $4626-4846$ & BC 2897-2677 \\
\hline KCIR-09 & $358.6-359.6$ & $\begin{array}{l}\text { G. Ruber, G. } \\
\text { Sacculifer }\end{array}$ & $3815 \pm 30$ & $3447-3695$ & BC 1746-1498 \\
\hline KCIR-09 & $372.3-373.3$ & $\begin{array}{l}\text { G. Ruber, G. } \\
\text { Sacculifer }\end{array}$ & $4745 \pm 30$ & $4679-4949$ & BC $3000-2730$ \\
\hline KCIR-10 & $0.5-1.5$ & Bulk & $1755 \pm 30$ & $1058-1265$ & AD 685-892 \\
\hline KCIR-10 & $636-637$ & Bulk & $3525 \pm 30$ & $3707-3884$ & BC 1411-1165 \\
\hline KCIR-11 & $1-2$ & Bulk & $1455 \pm 30$ & $740-940$ & AD 1010-1210 \\
\hline KCIR-11 & $273-274$ & Bulk & $3530 \pm 30$ & $3122-3365$ & BC 1416-1173 \\
\hline KCIR-11 & $379-380$ & Bulk & $10910 \pm 45$ & $11993-12474$ & BC 10525-10044 \\
\hline KCIR-12 & $398.1-399.2$ & Bulk & $3830 \pm 30$ & $3457-3718$ & BC 1769-1508 \\
\hline KCIR-12 & $572-573$ & Bulk & $12325 \pm 50$ & $13458-13800$ & BC 11851-11509 \\
\hline
\end{tabular}


Table 4

\begin{tabular}{|c|c|c|c|c|c|c|}
\hline Cores & $\begin{array}{c}\text { Top Augias } \\
\text { deposit } \\
\text { (cm) }\end{array}$ & $\begin{array}{l}\text { Base } \\
\text { Augias } \\
\text { deposit } \\
\text { (cm) }\end{array}$ & $\begin{array}{c}\text { Thickness } \\
\text { Augias } \\
\text { deposit } \\
\text { (cm) }\end{array}$ & $\begin{array}{l}\text { Sedimentation } \\
\text { rate }(\mathrm{cm} / \mathrm{ka})\end{array}$ & $\begin{array}{l}\text { Age of Augias } \\
\text { deposit BC }\end{array}$ & $\begin{array}{l}\text { Erosion } \\
\text { below Augias } \\
\text { deposit }(\mathrm{cm})\end{array}$ \\
\hline KCIR-03 & 249 & $?$ & & & & \\
\hline KCIR-05 & 54 & 148 & 94 & $28.3 \pm 0.1$ & $591.6 \pm 121$ & $27 \pm 3$ \\
\hline KCIR-08 & 68 & 454 & 386 & $23.3 \pm 0.6$ & $127.8 \pm 122$ & $11 \pm 4$ \\
\hline KCIR-09 & 26 & 341 & 315 & $8.2 \pm 0.1$ & $269.3 \pm 136$ & $5.2 \pm 1$ \\
\hline KCIR-10 & 20 & 635 & 615 & $9.9 \pm 0.1$ & $1115.4 \pm 104$ & $14.8 \pm 1$ \\
\hline KCIR-11 & 9.5 & 254 & 244.5 & $11.2 \pm 0.2$ & $1160.4 \pm 123$ & $17 \pm 1$ \\
\hline KCIR-12 & 20 & 394 & 374 & $17.3 \pm 0.1$ & $1407.6 \pm 131$ & $30.7 \pm 2$ \\
\hline
\end{tabular}


Table 5

\begin{tabular}{|c|c|c|c|c|c|c|}
\hline Name of facies & Facies 1: Thick sandy turbidite & \multicolumn{3}{|c|}{ Facies 2: Megaturbidite } & \multicolumn{2}{|c|}{ Facies 3: Homogenite } \\
\hline Location & $\begin{array}{c}\text { Northwestern part of the Calabrian } \\
\text { accretionary wedge }\end{array}$ & \multicolumn{3}{|c|}{ Southern boundary of the Calabrian accretionary wedge } & \multicolumn{2}{|c|}{ Small perched basin } \\
\hline Cores & KCIR-05 & KCIR-08 & KCIR-09 & $\mathrm{KCIR}-12$ & KCIR-10 & KCIR-11 \\
\hline $\begin{array}{l}\text { Thickness of Augias base } \\
\text { deposit }(\mathrm{cm})\end{array}$ & 43 & 114 & 93 & 100 & 9 & 1 \\
\hline \multirow{2}{*}{ Geochemical } & low Calcium & \multicolumn{3}{|c|}{ higher Calcium } & \multicolumn{2}{|c|}{ higher Calcium } \\
\hline & Peak Bromium & & & & & \\
\hline \multicolumn{7}{|l|}{ Composition: } \\
\hline Planktonic foraminifera & $\mathrm{x}$ & $\mathrm{x}$ & $\mathrm{x}$ & $\mathrm{x}$ & $\mathrm{X}$ & $\mathrm{x}$ \\
\hline Mineral & fragment of micas & fragment of micas & & fragment of micas & & \\
\hline Pteropod fragment & & $\mathrm{x}$ & $\mathrm{x}$ & & & \\
\hline Pyritized vegetal debris & $\mathrm{x}$ & & & & & \\
\hline Volcanic pumice & & $\mathrm{x}$ & & & & \\
\hline Sponge spicule & & & & & \multicolumn{2}{|l|}{$\mathrm{x}$} \\
\hline$\%$ sand & $>75 \%$ & $50-75 \%$ & $50 \%$ & $25 \%$ & \multicolumn{2}{|c|}{$<25 \%$} \\
\hline Erosive? & Yes & Yes & Yes & Yes & Yes & Yes \\
\hline \multirow{3}{*}{ Other information } & & \multicolumn{3}{|c|}{ laminated } & \multirow{3}{*}{\multicolumn{2}{|c|}{ No sedimentary structures }} \\
\hline & & divided in two part & & & & \\
\hline & & peak of magnetic suceptibility & & & & \\
\hline Sedimentary processes & High-energy turbidity current & \multicolumn{3}{|c|}{ Turbidity current triggered by earthquake and/or tsunami } & \multicolumn{2}{|c|}{$\begin{array}{l}\text { Remobilisation and decantation } \\
\text { of a nepheloid cloud (reworked } \\
\text { the unconsolidated sediment) }\end{array}$} \\
\hline Origin of sediment & Messina strait area & \multicolumn{3}{|c|}{ Sicilian margin } & \multicolumn{2}{|c|}{ local sediment } \\
\hline
\end{tabular}

